\title{
Second Quarter Hanford Seismic Report for Fiscal Year 2009
}

Pacific Northwest National Laboratory

Hanford Seismic Assessment Team

AC Rohay RE Clayton

MD Sweeney JL Devary

DC Hartshorn

July 2009 


\title{
DISCLAIMER
}

This report was prepared as an account of work sponsored by an agency of the United States Government. Neither the United States Government nor any agency thereof, nor Battelle Memorial Institute, nor any of their employees, makes any warranty, express or implied, or assumes any legal liability or responsibility for the accuracy, completeness, or usefulness of any information, apparatus, product, or process diselosed, or represents that its use would not infringe privately owned rights. Reference herein to any specific commercial product, process, or service by trade name, trademark, manufacturer, or otherwise does not necessarily constitute or imply its endorsement, recommendation, or favoring by the United States Government or any agency thereof, or Battelle Memorial Institute. The views and opinions of authors expressed herein do not necessarily state or reflect those of the United States Government or any agency thereof.

\author{
PACIFIC NORTHWEST NATIONAL LABORATORY \\ operated by \\ BATTELLE \\ for the \\ UNITED STATES DEPARTMENT OF ENERGY \\ under Contract DE-AC05-76RL01830 \\ Printed in the United States of America \\ Available to DOE and DOE contractors from the \\ Office of Scientific and Technical Information, \\ P.O. Box 62, Oak Ridge, TN 37831-0062; \\ ph: (865) 576-8401 \\ fax: $(865)$ 576-5728 \\ email: reports@adonis.osti.gov

\footnotetext{
Available to the public from the National Technical Information Service, U.S. Department of Commerce, 5285 Port Royal Rd., Springfield, VA 22161 ph: (800) 553-6847 fax: (703) 605-6900 email: orders@ntis.fedworld.gov online ordering: http://www.ntis.gov/ordering.htm
} 
PNNL-18633

\section{Second Quarter Hanford Seismic Report} for Fiscal Year 2009
A. C. Rohay
M. D. Sweeney
D. C. Hartshorn
R. E. Clayton
J. L. Devary

July 2009

Prepared for

the U.S. Department of Energy

under Contract DE-AC05-76RL01830

Pacific Northwest National Laboratory

Richland, Washington 99352 



\section{Summary}

The Hanford Seismic Assessment Program (HSAP) provides an uninterrupted collection of highquality raw and processed seismic data from the Hanford Seismic Network for the U.S. Department of Energy and its contractors. The HSAP is responsible for locating and identifying sources of seismic activity and monitoring changes in the historical pattern of seismic activity at the Hanford Site. The data are compiled, archived, and published for use by the Hanford Site for waste management, natural phenomena hazards assessments, and engineering design and construction. In addition, the HSAP works with the Hanford Site Emergency Services Organization to provide assistance in the event of a significant earthquake on the Hanford Site. The Hanford Seismic Network and the Eastern Washington Regional Network consist of 44 individual sensor sites and 15 radio relay sites maintained by the Hanford Seismic Assessment Team.

The Hanford Seismic Network recorded over 800 local earthquakes during the second quarter of FY 2009. Nearly all of these earthquakes were detected in the vicinity of Wooded Island, located about eight miles north of Richland just west of the Columbia River. Most of the events were considered minor (magnitude $\left(\mathrm{M}_{\mathrm{c})}\right.$ less than 1.0) with 19 events in the 2.0-2.9 range. The estimated depths of the Wooded Island events are shallow (averaging less than $1.0 \mathrm{~km}$ deep) with a maximum depth estimated at $1.9 \mathrm{~km}$. This places the Wooded Island events within the Columbia River Basalt Group (CRBG).

The low magnitude of the Wooded Island events has made them undetectable to all but local area residents. However, some Hanford employees working within a few miles of the area of highest activity and individuals living in homes directly across the Columbia River from the swarm center have reported feeling many of the larger magnitude events.

The Hanford Strong Motion Accelerometer (SMA) network was triggered numerous times by the Wooded Island swarm events. The maximum acceleration values recorded by the SMA network were approximately 2-3 times lower than the reportable action level for Hanford facilities ( $2 \% \mathrm{~g})$ and no action was required.

The swarming is likely due to pressure that has built up, cracking the brittle basalt layers within the Columbia River Basalt Formation (CRBG). Similar earthquake "swarms" have been recorded near this same location in 1970, 1975 and 1988. Prior to the 1970s, swarming may have occurred, but equipment was not in place to record those events.

Quakes of this limited magnitude do not pose a risk to Hanford cleanup efforts or waste storage facilities. Since swarms of the past did not intensify in magnitude, seismologists do not expect that these events will increase in intensity. However, Pacific Northwest National Laboratory (PNNL) will continue to monitor the activity.

Outside of the Wooded Island swarm, four earthquakes were recorded. Three earthquakes were classified as minor and one event registered $2.3 \mathrm{M}_{\mathrm{c}}$. One earthquake was located at intermediate depth (between 4 and $9 \mathrm{~km}$, most likely in the pre-basalt sediments) and three earthquakes at depths greater than 
$9 \mathrm{~km}$, within the basement. Geographically, two earthquakes were located in known swarm areas and two earthquakes were classified as random events. 


\section{Abbreviations and Acronyms}

$\begin{array}{ll}\text { BWIP } & \text { Basalt Waste Isolation Project } \\ \text { CRBG } & \text { Columbia River Basalt Group } \\ \text { DOE } & \text { U.S. Department of Energy } \\ \text { ETNA } & \text { strong motion accelerometer manufactured by Kinemetrics } \\ \text { EWRN } & \text { Eastern Washington Regional Network } \\ \text { FY } & \text { fiscal year } \\ \text { GPRS } & \text { General Packet Radio Service } \\ \text { GPS } & \text { Global Positioning System } \\ \text { HSAP } & \text { Hanford Seismic Assessment Program } \\ \text { HSN } & \text { Hanford Seismic Network } \\ \text { M }_{c} & \text { coda-length magnitude } \\ M_{L} & \text { local magnitude } \\ \text { PNNL } & \text { Pacific Northwest National Laboratory } \\ \text { SMA } & \text { strong motion accelerometer } \\ \text { USGS } & \text { U.S. Geological Survey } \\ \text { UTC } & \text { Coordinated Universal Time } \\ \text { UW } & \text { University of Washington } \\ \text { WHC } & \text { Westinghouse Hanford Company } \\ & \end{array}$




\section{Contents}

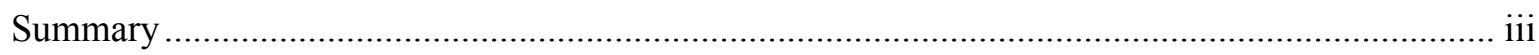

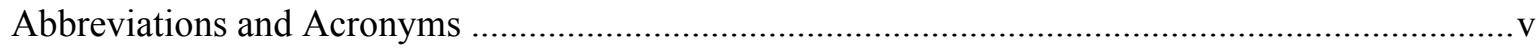

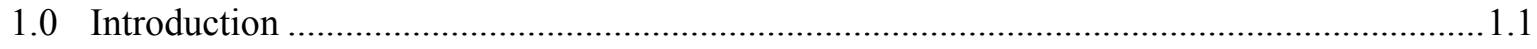

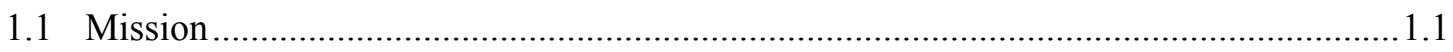

1.2 History of Monitoring Seismic Activity at Hanford .................................................... 1.1

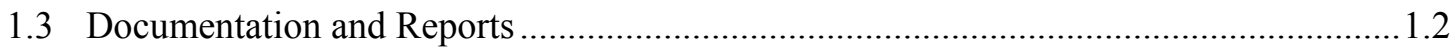

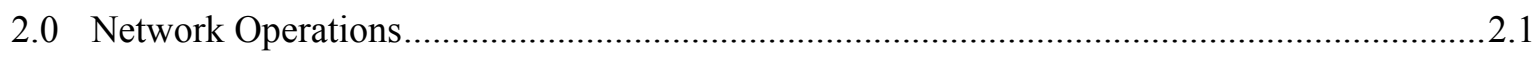

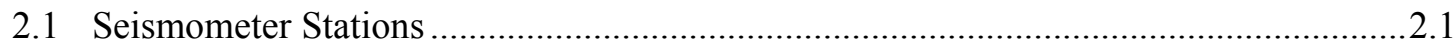

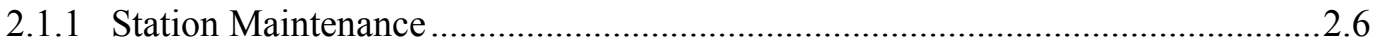

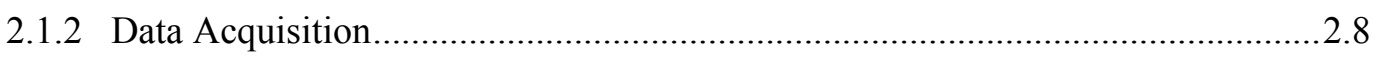

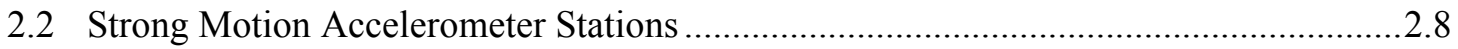

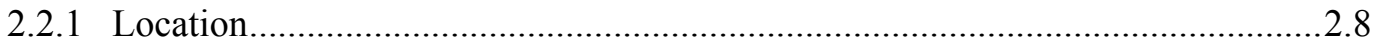

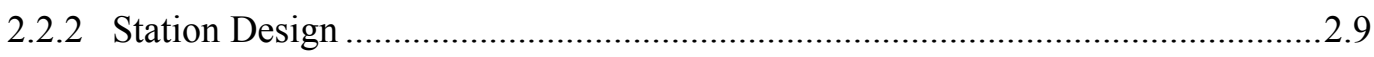

2.2.3 Strong Motion Accelerometer Operations Center ...........................................2.11

2.2.4 Strong Motion Operational Characteristics .....................................................2.11

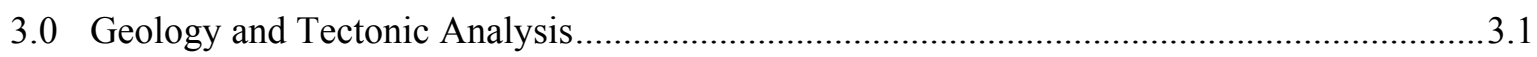

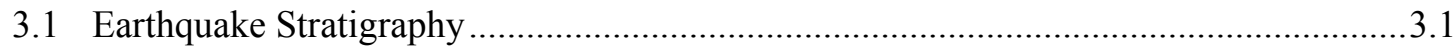

3.2 Geologic Structure Beneath the Monitored Area ........................................................ 3.1

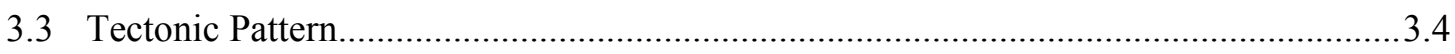

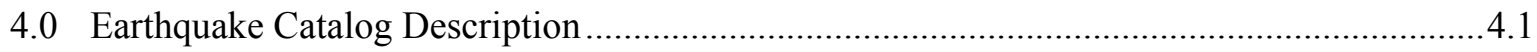

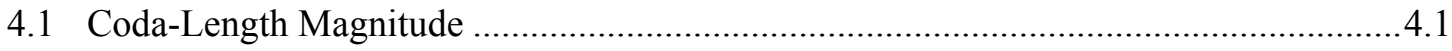

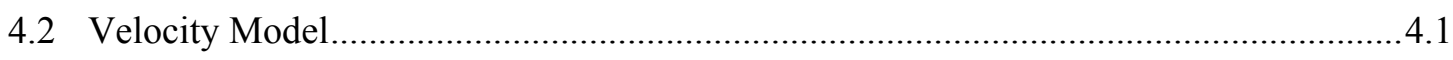

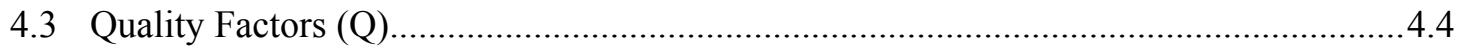

5.0 Seismic Activity - Second Quarter FY 2009 ................................................................ 5.1

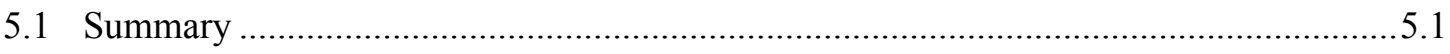

5.2 Second Quarter FY 2009 Earthquakes ................................................................... 5.1

5.2.1 Location and Depth of Earthquakes .............................................................. 5.2

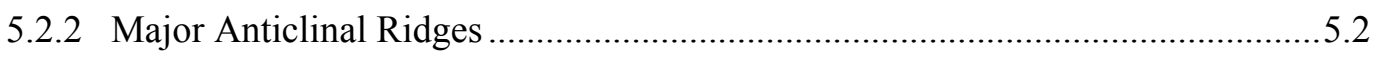

5.2.3 Earthquake Swarm Areas ........................................................................... 5.2

5.2.4 Random or Floating Events ......................................................................5.5

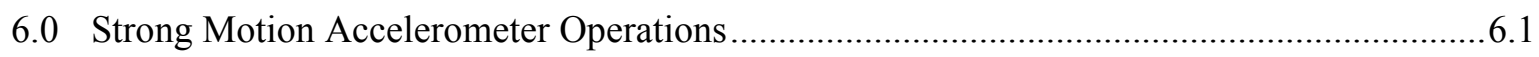

6.1 Second Quarter FY 2009 Triggers of the Hanford SMA Network ................................. 6.1

7.0 Capabilities in the Event of a Significant Earthquake ....................................................... 7.1

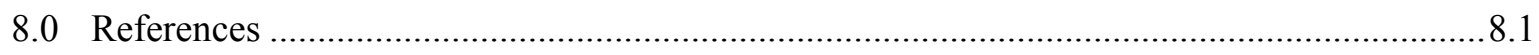




\section{Figures}

Figure 2.1. Seismometer and Strong Motion Accelerometer Stations in the Hanford Seismic

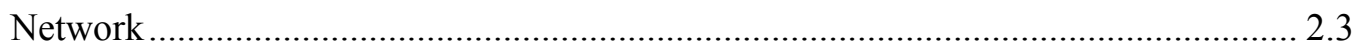

Figure 2.2. Seismometer Stations in the Eastern Washington Regional Network ......................... 2.5

Figure 2.3. Schematic Diagram of a Strong Motion Accelerometer Installation.......................... 2.10

Figure 3.1. Physical and Structural Geology of the Hanford Site, Washington ........................... 3.2

Figure 3.2. Geologic Cross Sections through the Columbia Basin (Reidel et al. 1994) ................. 3.3

Figure 5.1. Earthquakes Occurring in the Hanford Monitoring Area Between January 1, 2009 and March 31, 2009 (second quarter) ........................................................................ 5.4

Figure 5.2. Cross-Sectional Depiction (along 119W30 longitude) of Earthquakes Occurring in the Hanford Monitoring Area between January 1, 2009 and March 31, 2009 (second

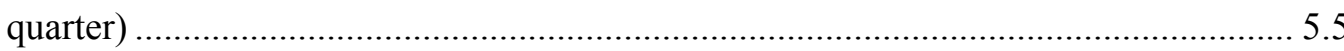

Figure 6.1. Acceleration Records from the 02/21/2009 magnitude 2.9 Swarm Event at the 300 Area SMA

Figure 6.2. Acceleration Records from the January 30, 2009 Poulsbo Event at the $100 \mathrm{~K}$ Area SMA

\section{Tables}

Table 2.1. Seismometer Stations in the Hanford Seismic Network ............................................. 2.2

Table 2.2. Seismometer Stations in the Eastern Washington Regional Network ........................... 2.4

Table 2.3. Free-Field Strong Motion Accelerometer Sites ....................................................... 2.9

Table 2.4. Instrument Parameters for the Kinemetrics ETNA System in the Hanford SMA

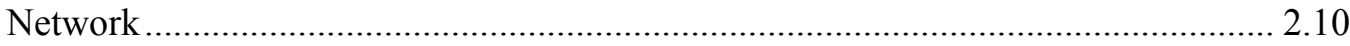

Table 3.1. Thicknesses of Stratigraphic Units in the Monitoring Area (from Reidel et al. 1994).. 3.4

Table 4.1. Local Seismic Data, January 1 - March 31, 2009 ..................................................... 4.2

Table 4.2. Crustal Velocity Model for Eastern Washington (from Rohay et al. 1985) ................. 4.5

Table 5.1. Depth Distribution of Earthquakes for FY 2009 ....................................................... 5.1

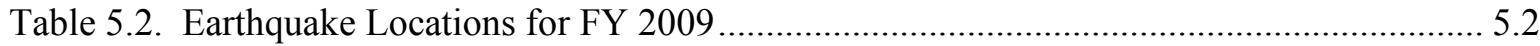

Table 6.1. Maximum Accelerations from the Highest Magnitude $\left(M_{c}\right)$ Wooded Island Earthquake Swarm Events 



\subsection{Introduction}

This quarterly report documents the locations, magnitudes, and seismic interpretations of earthquakes recorded for the Hanford monitoring region of south-central Washington during the second quarter of fiscal year (FY) 2009 (January 2009 through March 2009).

\subsection{Mission}

The principal mission of the Hanford Seismic Assessment Program (HSAP) is to maintain the seismometer and strong motion accelerometer (SMA) sites, report data from measured events, and provide assistance in the event of an earthquake. This mission supports the U.S. Department of Energy (DOE) and the other Hanford Site contractors in their compliance with DOE Order 420.1B, Chapter IV, Section 3.d "Seismic Detection" and DOE Order G 420.1-1, Section 4.7, "Emergency Preparedness and Emergency Communications." DOE Order 420.1B requires facilities or sites with hazardous materials to maintain instrumentation or other means to detect and record the occurrence and severity of the seismic event. The HSAP maintains the seismic network located on and around the Hanford Site. The data collected from the seismic network can be used to support facility or site operations to protect the public, workers, and the environment from the impact of seismic events.

In addition, the HSAP provides an uninterrupted collection of high-quality raw seismic data from the Hanford Seismic Network (HSN) and the Eastern Washington Regional Network (EWRN) and provides interpretations of seismic events from the Hanford Site and the vicinity. The program locates and identifies sources of seismic activity, monitors changes in the historical pattern of seismic activity, and builds a "local" earthquake database (processed data) that is permanently archived. The focus of this report is the precise location of earthquakes proximal to or on the Hanford Site, specifically, between $46-47^{\circ}$ north latitude and between $119-120^{\circ}$ west longitude. Data from the EWRN and other seismic networks in the Northwest provide the HSAP with necessary regional input for the seismic hazards analysis at the Hanford Site. These seismic data are used to support Hanford Site contractors for waste management activities, natural phenomena hazards assessments, and engineering design and construction.

\subsection{History of Monitoring Seismic Activity at Hanford}

Assessing seismic activity at the Hanford Site was initiated in 1969 by the U.S. Geological Survey (USGS) under a contract with the U.S. Atomic Energy Commission. In 1975, the University of Washington (UW) assumed responsibility for the network and subsequently expanded it. In 1979, the Basalt Waste Isolation Project (BWIP) became responsible for collecting seismic data for the Hanford Site as part of site characterization activities. Rockwell Hanford Operations, followed by Westinghouse Hanford Company (WHC), operated the local network and were the contract technical advisors for the EWRN operated and maintained by UW. Funding ended for BWIP in December 1988; the seismic program (including the UW contract) was transferred to the WHC Environmental Division. Maintenance 
responsibilities for the EWRN also were assigned to WHC, who made major upgrades to EWRN sites. Effective October 1, 1996, all seismic assessment activities were transferred to the Pacific Northwest National Laboratory (PNNL). ${ }^{1}$

The Hanford SMA network was constructed during 1997, becoming operational in May 1997. It was shut down in FY 1998 due to lack of funding but became operational again in FY 1999 and has operated continuously since that time.

\subsection{Documentation and Reports}

The HSAP issues quarterly reports of local activity, an annual catalog of earthquake activity in southeastern Washington, and special-interest bulletins on local seismic events. This includes information and special reports as requested by DOE and Hanford Site contractors. Earthquake information provided in these reports is subject to revision as new information becomes available. An archive of all seismic data from the HSAP is maintained by PNNL on computer servers.

\footnotetext{
${ }^{1}$ Pacific Northwest National Laboratory is operated by Battelle for the U.S. Department of Energy under Contract DE-AC05-76RL01830.
} 


\subsection{Network Operations}

\subsection{Seismometer Stations}

The seismic network consists of two types of earthquake sensors - seismometers and strong motion accelerometers (SMAs). Seismometers are designed primarily to detect micro earthquakes near Hanford recording seismograms that are used to determine the magnitudes and locations of seismic events. SMA stations are designed to measure ground motion and are discussed in Section 2.2.

The HSN and the EWRN consist of 44 seismometer stations. This includes three recently acquired Transportable Array (TA) stations located at Cold Creek (CCRK), Didier Farms (DDRF), and Phinney Hill (PHIN). The TA stations are tri-axial, broad-band seismometers with full digital telemetry capabilities. Most stations reside in remote locations and require solar panels and batteries for power. The HSN includes 26 stations (Table 2.1 and Figure 2.1), and the EWRN consists of 39 stations (Table 2.2 and Figure 2.2). Twenty-one stations are shared by both networks. Note that the Bickelton (BLT) and Phinney Hill (PHIN) stations are shown on Figure 2.2.

The EWRN is used by the HSAP for two major reasons. A large earthquake located in the Pacific Northwest outside of Hanford could produce significant ground motion and damage at the Hanford Site. For example, the magnitude 7.0 event that occurred in 1872 near Chelan/Entiat or other events located in the region (e.g., eastern Cascade mountain range) could have such an effect. The EWRN would provide valuable information to help determine the impacts of such an event. Additionally, the characterization of seismicity throughout the surrounding areas, as required for the Probabilistic Seismic Hazard Analysis, supports facility safety assessments at the Hanford Site. Both the HSN and the EWRN are fully integrated within the Pacific Northwest Seismic Network managed by the University of Washington. 
Table 2.1. Seismometer Stations in the Hanford Seismic Network

\begin{tabular}{|c|c|c|c|c|}
\hline Station $^{(a)}$ & $\begin{array}{c}\text { Latitude } \\
\text { Deg. Min. N. }\end{array}$ & $\begin{array}{c}\text { Longitude } \\
\text { Deg. Min. W. }\end{array}$ & Elevation (m) & Station Name \\
\hline $\mathrm{CCRK}^{(\mathrm{b})}$ & $46^{\circ} 55.85$ & $119^{\circ} 85.49$ & 560 & Cold Creek \\
\hline $\mathrm{DDRF}^{(\mathrm{b})}$ & $46^{\circ} 49.12$ & $119^{\circ} 05.96$ & 270 & Didier Farms \\
\hline $\mathrm{FHE}^{(\mathrm{b})}$ & $46^{\circ} 57.11$ & $119^{\circ} 29.82$ & 455 & Frenchman Hills East \\
\hline PHIN $^{(b)}$ & $45^{\circ} 89.52$ & $119^{\circ} 92.78$ & 270 & Phinney Hill \\
\hline $\mathrm{GBB}^{(\mathrm{b})}$ & $46^{\circ} 36.49$ & $119^{\circ} 37.62$ & 177 & Gable Butte \\
\hline BEN & $46^{\circ} 31.13$ & $119^{\circ} 43.02$ & 340 & Benson Ranch \\
\hline BLT & $45^{\circ} 54.91$ & $120^{\circ} 10.55$ & 659 & Bicklelton \\
\hline BRV & $46^{\circ} 29.12$ & $119^{\circ} 59.47$ & 920 & Black Rock Valley \\
\hline BVW & $46^{\circ} 48.66$ & $119^{\circ} 52.99$ & 670 & Beverly \\
\hline CRF & $46^{\circ} 49.50$ & $119^{\circ} 23.22$ & 189 & Corfu \\
\hline ET3 & $46^{\circ} 34.64$ & $118^{\circ} 56.25$ & 286 & Eltopia Three \\
\hline GBL & $46^{\circ} 35.92$ & $119^{\circ} 27.58$ & 330 & Gable Mountain \\
\hline $\mathrm{H} 2 \mathrm{O}$ & $46^{\circ} 23.75$ & $119^{\circ} 25.38$ & 158 & Water \\
\hline LOC & $46^{\circ} 43.02$ & $119^{\circ} 25.85$ & 210 & Locke Island \\
\hline MDW & $46^{\circ} 36.79$ & $119^{\circ} 45.66$ & 330 & Midway \\
\hline MJ2 & $46^{\circ} 33.45$ & $119^{\circ} 21.54$ & 146 & May Junction Two \\
\hline OT3 & $46^{\circ} 40.14$ & $119^{\circ} 13.98$ & 322 & Othello Three \\
\hline PRO & $46^{\circ} 12.73$ & $119^{\circ} 41.15$ & 550 & Prosser \\
\hline RED & $46^{\circ} 17.92$ & $119^{\circ} 26.30$ & 366 & Red Mountain \\
\hline RSW & $46^{\circ} 23.67$ & $119^{\circ} 35.48$ & 1,045 & Rattlesnake Mountain \\
\hline SNI & $46^{\circ} 27.85$ & $119^{\circ} 39.60$ & 312 & Snively Ranch \\
\hline VT2 & $46^{\circ} 58.04$ & $119^{\circ} 58.95$ & 387 & Vantage Two \\
\hline WA2 & $46^{\circ} 45.32$ & $119^{\circ} 33.94$ & 244 & Wahluke Slope \\
\hline WIW & $46^{\circ} 25.76$ & $119^{\circ} 17.26$ & 128 & Wooded Island \\
\hline WRD & $46^{\circ} 58.20$ & $119^{\circ} 08.69$ & 375 & Warden \\
\hline YPT & $46^{\circ} 02.93$ & $118^{\circ} 57.73$ & 325 & Yellepit \\
\hline \multicolumn{5}{|c|}{$\begin{array}{l}\text { (a) The first column is the alphanumeric seismic station designator. The latitude and longitude, elevation above sea level in } \\
\text { meters, and the full station name follow this. The locations of the stations all are in Washington; locations were derived } \\
\text { from the Global Positioning System (GPS). } \\
\text { (b) Three-component station. }\end{array}$} \\
\hline
\end{tabular}




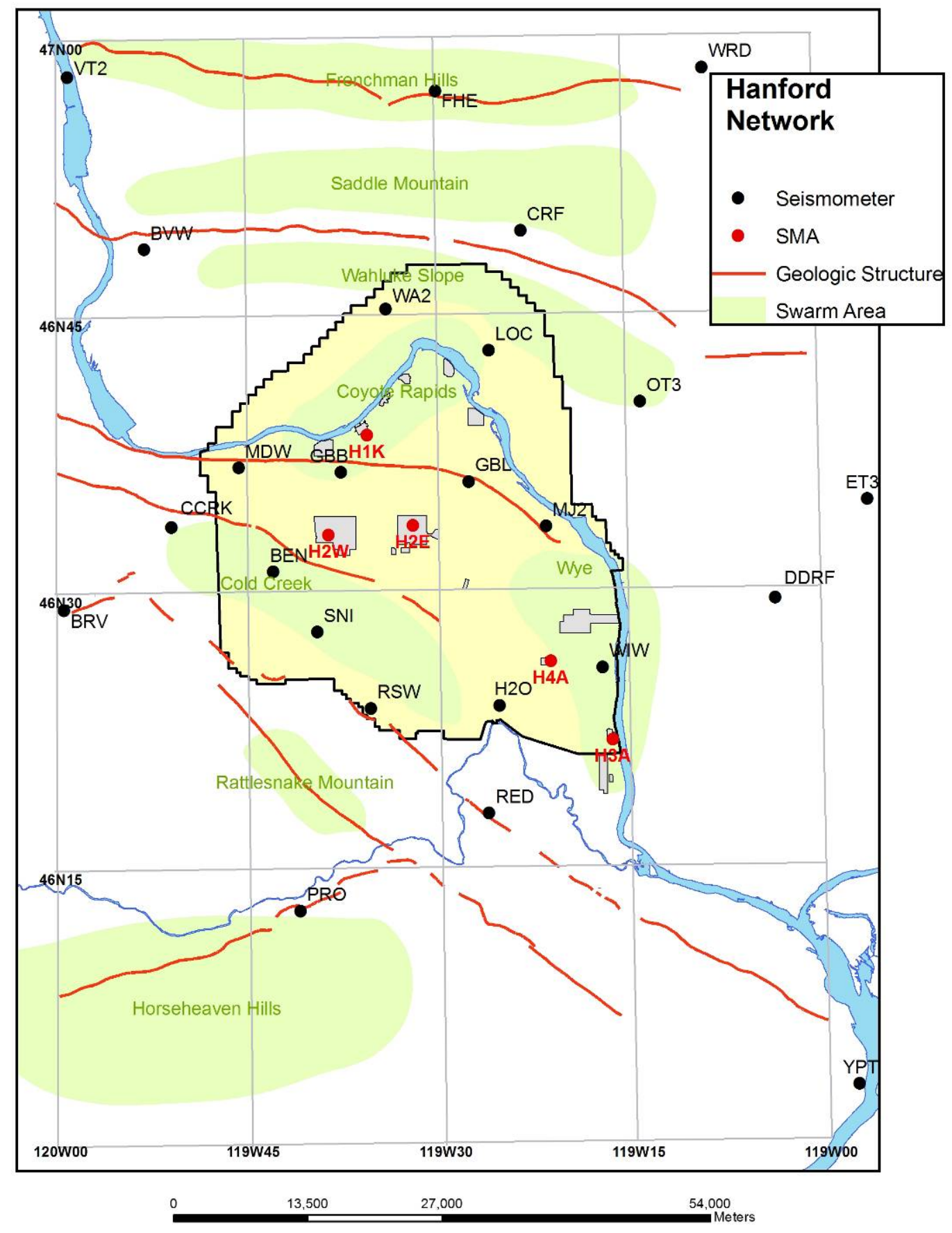

Figure 2.1. Seismometer and Strong Motion Accelerometer Stations in the Hanford Seismic Network 
Table 2.2. Seismometer Stations in the Eastern Washington Regional Network

\begin{tabular}{|c|c|c|c|c|}
\hline Station $^{(a)}$ & $\begin{array}{c}\text { Latitude } \\
\text { Deg. Min. N. }\end{array}$ & $\begin{array}{c}\text { Longitude } \\
\text { Deg. Min. W. }\end{array}$ & Elevation (m) & Station Name \\
\hline CCRK $^{(b)}$ & $46^{\circ} 55.85$ & $119^{\circ} 85.49$ & 560 & Cold Creek \\
\hline $\mathrm{DDRF}^{(\mathrm{b})}$ & $46^{\circ} 49.12$ & $119^{\circ} 05.96$ & 270 & Didier Farms \\
\hline $\mathrm{FHE}^{(\mathrm{b})}$ & $46^{\circ} 57.11$ & $119^{\circ} 29.82$ & 455 & Frenchman Hills East \\
\hline PHIN $^{(b)}$ & $45^{\circ} 89.52$ & $119^{\circ} 92.78$ & 270 & Phinney Hill \\
\hline BLT & $45^{\circ} 54.91$ & $120^{\circ} 10.55$ & 659 & Bickleton \\
\hline BRV & $46^{\circ} 29.12$ & $119^{\circ} 59.47$ & 920 & Black Rock Valley \\
\hline BVW & $46^{\circ} 48.66$ & $119^{\circ} 52.99$ & 670 & Beverly \\
\hline CBS & $47^{\circ} 48.26$ & $120^{\circ} 02.50$ & 1,067 & Chelan Butte South \\
\hline $\mathrm{CRF}$ & $46^{\circ} 49.50$ & $119^{\circ} 23.22$ & 189 & Corfu \\
\hline DPW & $47^{\circ} 52.25$ & $118^{\circ} 12.17$ & 892 & Davenport \\
\hline DY2 & $47^{\circ} 59.11$ & $119^{\circ} 46.28$ & 890 & Dyer Hill Two \\
\hline ELL & $46^{\circ} 54.58$ & $120^{\circ} 33.98$ & 789 & Ellensburg \\
\hline EPH & $47^{\circ} 21.38$ & $119^{\circ} 35.76$ & 661 & Ephrata \\
\hline ET3 & $46^{\circ} 34.64$ & $118^{\circ} 56.25$ & 286 & Eltopia Three \\
\hline ETW & $47^{\circ} 36.26$ & $120^{\circ} 19.94$ & 1,477 & Entiat \\
\hline GBL & $46^{\circ} 35.92$ & $119^{\circ} 27.58$ & 330 & Gable Mountain \\
\hline LNO & $45^{\circ} 52.31$ & $118^{\circ} 17.11$ & 771 & Lincton Mountain Oregon \\
\hline LOC & $46^{\circ} 43.02$ & $119^{\circ} 25.85$ & 210 & Locke Island \\
\hline MDW & $46^{\circ} 36.79$ & $119^{\circ} 45.66$ & 330 & Midway \\
\hline $\mathrm{MJ} 2$ & $46^{\circ} 33.45$ & $119^{\circ} 21.54$ & 146 & May Junction Two \\
\hline MOX & $46^{\circ} 34.64$ & $120^{\circ} 17.89$ & 501 & Moxee City \\
\hline NAC & $46^{\circ} 43.99$ & $120^{\circ} 49.42$ & 728 & Naches \\
\hline NEL & $48^{\circ} 04.21$ & $120^{\circ} 20.41$ & 1,500 & Nelson Butte \\
\hline OD2 & $47^{\circ} 23.26$ & $118^{\circ} 42.58$ & 553 & Odessa Two \\
\hline OT3 & $46^{\circ} 40.14$ & $119^{\circ} 13.98$ & 322 & Othello Three \\
\hline PAT2 & $45^{\circ} 53.03$ & $119^{\circ} 45.40$ & 259 & Paterson Two \\
\hline PRO & $46^{\circ} 12.73$ & $119^{\circ} 41.15$ & 550 & Prosser \\
\hline RSW & $46^{\circ} 23.67$ & $119^{\circ} 35.48$ & 1,045 & Rattlesnake Mountain \\
\hline SAW & $47^{\circ} 42.10$ & $119^{\circ} 24.03$ & 701 & St. Andrews \\
\hline TBM & $47^{\circ} 10.20$ & $120^{\circ} 35.88$ & 1,006 & Table Mountain \\
\hline TRW & $46^{\circ} 17.32$ & $120^{\circ} 32.31$ & 723 & Toppenish Ridge \\
\hline TWW & $47^{\circ} 08.29$ & $120^{\circ} 52.10$ & 1,027 & Teanaway \\
\hline VT2 & $46^{\circ} 58.04$ & $119^{\circ} 58.95$ & 387 & Vantage Two \\
\hline WA2 & $46^{\circ} 45.32$ & $119^{\circ} 33.94$ & 244 & Wahluke Slope Two \\
\hline WAT & $47^{\circ} 41.92$ & $119^{\circ} 57.24$ & 821 & Waterville \\
\hline WIW & $46^{\circ} 25.76$ & $119^{\circ} 17.26$ & 128 & Wooded Island \\
\hline WRD & $46^{\circ} 58.20$ & $119^{\circ} 08.69$ & 375 & Warden \\
\hline YA2 & $46^{\circ} 31.60$ & $120^{\circ} 31.80$ & 652 & Yakima Two \\
\hline YPT & $46^{\circ} 02.93$ & $118^{\circ} 57.73$ & 325 & Yellepit \\
\hline
\end{tabular}

(a) The first column is the alphanumeric seismic station designator. The latitude and longitude, elevation above sea level in meters, and the full station name follow this. The locations of the stations all are in Washington unless otherwise indicated; locations were determined from the Global Positioning System (GPS).

(b) Three-component station. 


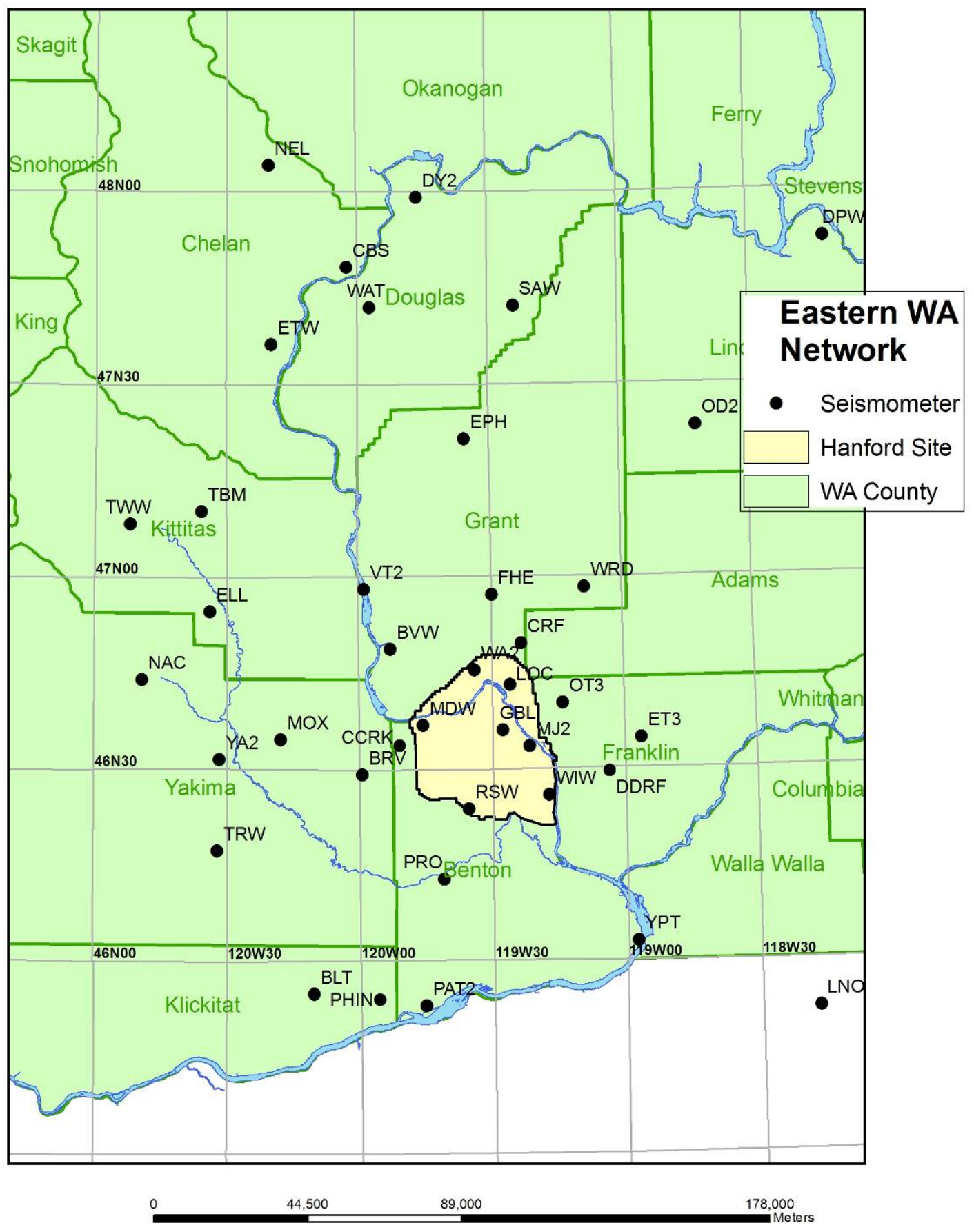

Figure 2.2. Seismometer Stations in the Eastern Washington Regional Network 
The HSN and EWRN networks have 54 combined data channels because the five three-component sites (Gable Butte, Frenchman Hills East, Cold Creek, Didier Farms, and Phinney Hill) require 2 additional data channels per station. The tri-axial stations record motion in the vertical, north-south horizontal, and east-west horizontal directions. The other 39 stations are single vertical component seismometers. Fifteen radio telemetry relay sites are used by both networks to continuously transmit seismogram data to the Seismic Assessment Laboratory in the Sigma V building, Richland, Washington, for processing and archiving.

\subsubsection{Station Maintenance}

The second quarter of FY 2009 presented unique challenges to the station maintenance effort. The Hanford Seismic Network recorded over 800 local earthquakes in the vicinity of Wooded Island, located about eight miles north of Richland just west of the Columbia River. Most of the events were considered minor with the maximum magnitude estimated at $2.9\left(\mathrm{M}_{\mathrm{c}}\right)$. This increase in seismic activity at Wooded Island had been previously observed in 1970, 1975, and 1988.

Three temporary seismometer stations (WIXX, WIA, and WIB) were installed to enhance the monitoring of the Wooded Island swarm. Locations of the new stations are shown in Figure 5.1. The WIXX station (Figure 2.3) utilized equipment dedicated to the upgraded Gable Butte (GBB) station that is being upgraded to include digital electronics and web-based telemetry. The WIXX station will remain at its present location until the activity of the Wooded Island swarm subsides.

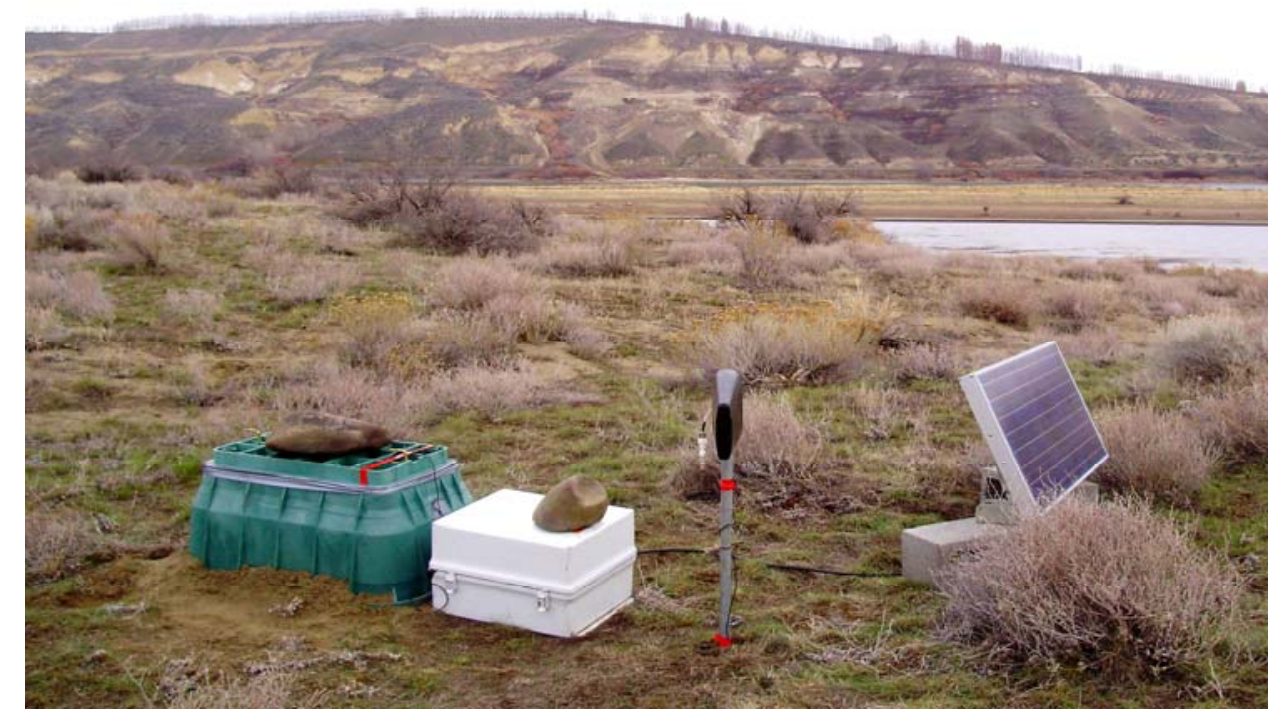

Figure 2.3. WIXX broadband site near Wooded Island Swarm

Two other sites (WIA and WIB) were installed and equipped with ETNA Strong Motion Accelerometers (SMAs). The three new stations supplemented the established seismometer station (WIW) located near Wooded Island. Additionally, the 300 Area and 400 Area SMAs were used to monitor the Wooded Island swarm. Monitoring at these five additional stations added to the normal maintenance efforts for the second quarter. 
Another significant event during the second quarter was the loss of power on the summit of Rattlesnake Mountain (elevation $3527 \mathrm{ft}$.) in February. The failure of a high voltage fuse on a Benton County Public Utility (PUD) power pole triggered an evaluation of the electrical system in the unused $6652 \mathrm{C}$ building (Figure 2.4). This building houses the AC powered repeater station (RSWR), a central high elevation hub for the Eastern Washington Regional Network (EWRN). The electrical evaluation revealed that the insulation for the underground wiring had degraded over the years and no longer met safety requirements. The seismic maintenance crew installed 12 volt batteries with solar panels as the primary electrical source for the RSWR repeater station. This configuration will not be feasible during the winter months when sunlight is more limited.

To resolve this situation, efforts are currently underway to obtain alternate transmission pathways from the distant EWRN stations (BLT, PAT2, ET3, LNO, MJ2, RSW, EPH, OD2, WRD, DY2, ETW, SAW, WAT, CBS, YPT, and NEL). Preserving continuous data transmissions from these sites without the RSWR repeater station is essential for status monitoring and troubleshooting purposes.

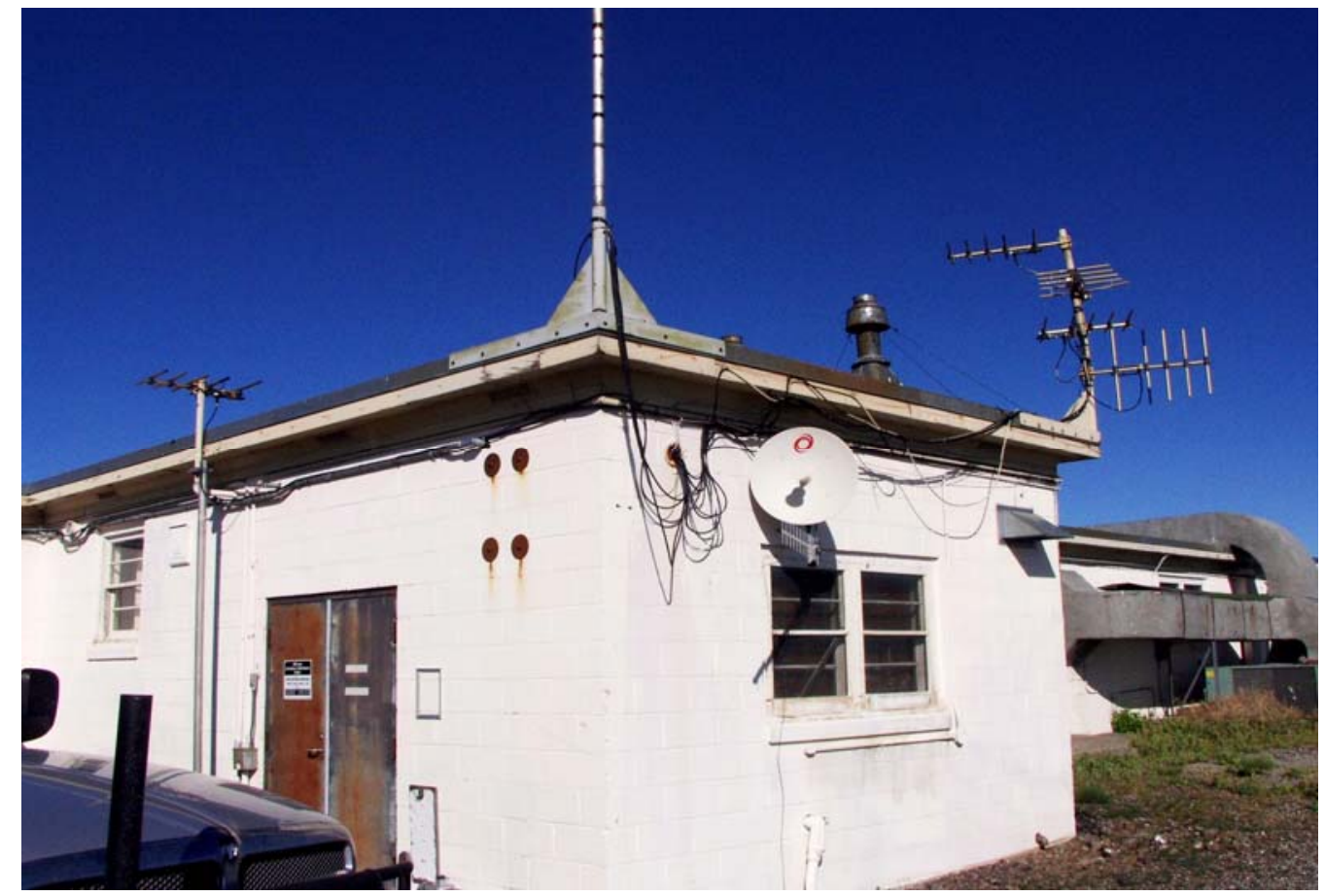

Figure 2.4. Building $6652 \mathrm{C}$ to be demolished under current DOE plan.

Cloudy weather necessitated battery replacement at several seismometer stations. Cattle damage required repairs at the Lincton Mountain site (LNO). The Ephrata relay (EPHR) and seismic site (EPH) were vandalized with the solar panel, electronics, and batteries being stolen. The equipment was replaced and the stations resumed operations. Relocation sites are being examined that are more secure from public access. 


\subsubsection{Data Acquisition}

The signals from the seismometer stations are monitored for changes in signal amplitude that are expected from earthquakes. The seismic network is subdivided into spatial groupings of stations that are monitored for nearly simultaneous amplitude changes, resulting in triggering a permanent recording of the events. The groupings and associated weighting schemes are designed to allow very small seismic events to be recorded and to minimize false triggers. Events are classified as local (south-central Washington near the Hanford Site), regional (western United States and Canada), and teleseisms (from farther distances around the world). Local and regional events are usually earthquakes, but quarry and mining explosions also are recorded. Quarry and mining explosions usually can be identified from wave characteristics and the time of occurrence and may be confirmed with local government agencies and industries. Frequently, military exercises at the U.S. Army Yakima Training Center produce a series of acoustic shocks that trigger the recording system. Sonic booms and thunder also produce acoustic signals that may trigger the recording system.

The HSAP uses Earthworm, a PC-based system developed by the USGS and used by the Pacific Northwest Seismic Network at the UW, to record triggered events. One Earthworm system has been in continuous operation since January 6, 1999. A second system was installed in mid-March 1999. Both systems have been running in parallel since that time, with periodic hardware and software upgrades performed. Seismogram data from triggered events are collected on a SUN workstation (Sun Microsystems, Santa Clara, California) for assessment by HSAP staff. This information is evaluated to determine if the event is "false" (for example, due to a sonic boom) or is an earthquake or ground-surface or underground blast. Earthquake events are evaluated to determine epicenter locations, focal depths, and magnitudes (Section 4).

Although the two Earthworm systems are practically identical, slight differences in the trigger algorithms, combined with the granularity of the signal-measurement time windows, sometimes result in triggered events from one Earthworm system but not the other. These different or exclusive events are generally "false" triggers resulting from acoustical sources and not earthquakes or quarry blasts. Sometimes these exclusive events correspond to barely detectable, distant regional, or teleseismic earthquakes.

\subsection{Strong Motion Accelerometer Stations}

\subsubsection{Location}

The Hanford SMA network consists of five free-field SMA stations (see Figure 2.1; Table 2.3). SMAs are located in the 200 East and 200 West Areas, in the 100-K Area adjacent to the K Basins, in the 400 Area near the former Fast Flux Test Facility, and at the south end of the 300 Area.

The locations of SMA stations were chosen based on two criteria: 1) density of workers and 2) siting of hazardous facilities (Moore and Reidel 1996). The 200 East and 200 West Areas contain single-shell and double-shell tanks in which high-level radioactive wastes from past processing of fuel rods are stored. In addition, the Canister Storage Facility (holding encapsulated spent fuel rods) and the new Waste Treatment and Immobilization Plant being constructed are both located in the 200 East Area. The 100-K Area contains the K Basins, where spent fuel rods from the N Reactor were stored prior to encapsulation. 
Table 2.3. Free-Field Strong Motion Accelerometer Sites

\begin{tabular}{|c|c|c|c|}
\hline Site & Site ID & Location & $\begin{array}{c}\text { Latitude } \\
\text { Longitude } \\
\text { Elevation }\end{array}$ \\
\hline $100 \mathrm{~K}$ Area & $\mathrm{H} 1 \mathrm{~K}$ & South of K Basins outside 100 Area fence lines & $\begin{array}{l}46^{\circ} 38.51^{\prime} \\
119^{\circ} 35.53^{\prime} \\
152 \mathrm{~m}\end{array}$ \\
\hline 200 East Area & $\mathrm{H} 2 \mathrm{E}$ & $\begin{array}{l}\text { East of B Plant; northwest of Waste Treatment and Immobilization } \\
\text { Plant; north of } 7 \text { th Street and east of Baltimore Avenue }\end{array}$ & $\begin{array}{l}46^{\circ} 33.58^{\prime} \\
119^{\circ} 32.00^{\prime} \\
210 \mathrm{~m}\end{array}$ \\
\hline 200 West Area & $\mathrm{H} 2 \mathrm{~W}$ & $\begin{array}{l}\text { West of Plutonium Finishing Plant (PFP) and } 200 \text { West Area tree } \\
\text { barrier }\end{array}$ & $\begin{array}{l}46^{\circ} 33.11^{\prime} \\
119^{\circ} 38.64^{\prime} \\
201 \mathrm{~m}\end{array}$ \\
\hline 300 Area & $\mathrm{H} 3 \mathrm{~A}$ & $\begin{array}{l}\text { South end of } 300 \text { Area inside fence lines (NE 1/4, SW 1/4, Sec. 11, } \\
\text { T10N, R28E) }\end{array}$ & $\begin{array}{l}46^{\circ} 21.83^{\prime} \\
119^{\circ} 16.55^{\circ} \\
119 \mathrm{~m}\end{array}$ \\
\hline 400 Area & $\mathrm{H} 4 \mathrm{~A}$ & $\begin{array}{l}500 \mathrm{ft} \text { from fence line on east side of facility and north of parking } \\
\text { area) }\end{array}$ & $\begin{array}{l}46^{\circ} 26.13^{\prime} \\
119^{\circ} 21.30^{\prime} \\
171 \mathrm{~m}\end{array}$ \\
\hline
\end{tabular}

The Cold Vacuum Drying Facility, also located in the 100-K Area, is used to encapsulate spent fuel rods from the K Basins prior to shipment to the Canister Storage Building in the 200 East Area. The 400 Area is the site of construction activities.

\subsubsection{Station Design}

All free-field SMA stations consist of a four-panel solar array and two 30-gal galvanized drums that contain equipment. Each panel has a maximum $42-\mathrm{W}$ output. The two 30 -gal drums are set in the ground such that the base of each drum is about $1 \mathrm{~m}$ below the ground surface. One drum houses only the SMA; the other drum, which is connected via a sealed conduit to the SMA drum, contains the batteries. Data communication is provided by a General Packet Radio Service (GPRS) system, a continuous radio datalink to an Internet service provider. The GPRS system along with the solar power regulator is housed in a small enclosure mounted at the rear of the solar array. The enclosure serves as a junction box for all cabling between equipment inside and outside the drums through conduit. The antenna for the GPRS is mounted on top of the enclosure. The enclosure permits quick access to check battery conditions and a connection directly to the RS-232 port of the SMA without removing the drum lids.

The SMA stations are three-component units consisting of vertical, north-south horizontal, and eastwest horizontal seismometers manufactured by Kinemetrics, Inc., Pasadena, California, and known as the ETNA system (specifications summarized in Table 2.4). Each ETNA unit contains a digital recorder, a data storage unit, and a Global Positioning System (GPS) receiver (Figure 2.5) with the equipment housed in a watertight box. 
Table 2.4. Instrument Parameters for the Kinemetrics ETNA System in the Hanford SMA Network

\begin{tabular}{||l|l||}
\hline \multicolumn{1}{|c|}{ Parameter } & \multicolumn{1}{|c|}{ Sensor } \\
\hline \hline \multicolumn{2}{|c||}{ Value or Range } \\
\hline Type & Triaxial EpiSensor Accelerometer \\
\hline Frequency range & $\pm 2 \mathrm{~g}^{(\mathrm{a})}$ \\
\hline Damping & $0-80 \mathrm{~Hz}$ \\
\hline \multicolumn{2}{|c||}{ Approximately $70 \%$ critical ${ }^{(\mathrm{a})}$} \\
\hline Number of channels & 3 \\
\hline Sample rate & $200 \mathrm{samples} / \mathrm{sec}$ \\
\hline Resolution & 18 bits \\
\hline Digital output & Real-time, RS-232 output stream \\
\hline \multicolumn{2}{|l||}{ Seismic Trigger } \\
\hline Filter & $0.1-12.5 \mathrm{~Hz}$ \\
\hline Trigger level & $0.02 \% \mathrm{~g}$ (b) \\
\hline Alarm (call-out) threshold & Not activated \\
\hline Pre-event memory & $10 \mathrm{~s}$ \\
\hline Post-event time & $40 \mathrm{~s}$ \\
\hline $\begin{array}{l}\text { (a) Setting is dependent on instrument calibration. } \\
\text { (b) See Section } 2.2 .4 \text { for discussion of trigger thresholds. }\end{array}$ \\
\hline
\end{tabular}

Figure 2.3. Schematic Diagram of a Strong Motion Accelerometer Installation

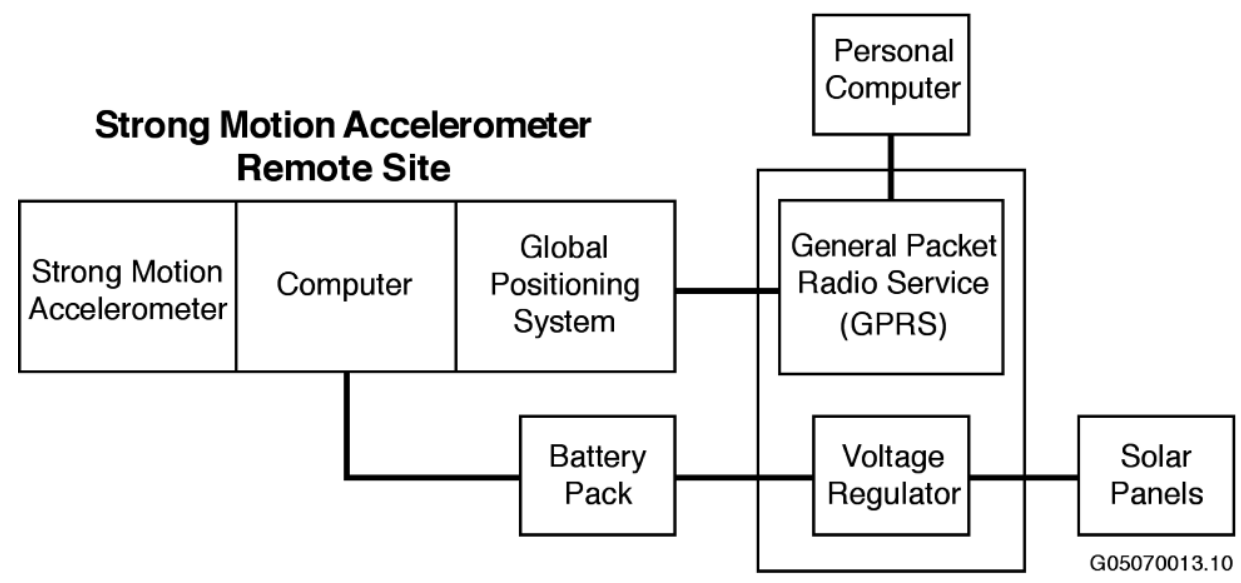

The GPRS system provides the Internet address connection to access the system. Stations can be monitored from any computer with appropriate access, and data can be downloaded to a dedicated computer in the Seismic Assessment Laboratory. The data also can be downloaded directly at each site via a built-in cable connection at the enclosure in case of communication failure. 
The GPS receiver is used principally to access the National Bureau of Standards timing system. The GPS receiver antenna is mounted on the enclosure at the rear of the solar array. The GPS receiver is activated internally approximately every $4 \mathrm{hr}$ and checks the "location of the instrument" and the time.

Any differences between the internal clock and the GPS time are recorded by the SMA. Any corrections to the internal timing are made automatically. Typically, the greatest correction recorded is approximately 4 milliseconds (ms).

\subsubsection{Strong Motion Accelerometer Operations Center}

The combined operations, data recording, data interpretation, and maintenance facility is located in the Sigma V Building and is operated by the HSAP.

\subsubsection{Strong Motion Operational Characteristics}

Signals from the three accelerometer channels use an 18-bit digitizer with data temporarily stored in a memory buffer. The digital sampling rate is 200 samples/s. The three channels are monitored for signals that exceed a programmable trigger threshold. When one accelerometer channel is triggered, the other channels automatically record. The nominal threshold used from 1998 to 2006 was $0.1 \% \mathrm{~g}(0.05 \%$ of the full-scale range of $2.0 \mathrm{~g}$; $\mathrm{g}$ is the acceleration of gravity, $9.8 \mathrm{~m} / \mathrm{s}^{2}$ or $32 \mathrm{ft} / \mathrm{s}^{2}$ ). Threshold trigger levels are set to trigger infrequently on noise sources (e.g., vehicles, sonic booms) near each site. In 2006, larger data storage capacities were installed that allowed the trigger thresholds to be reduced to $0.02 \% \mathrm{~g}$ (see Section 6). This permits the recording of ground motion data for smaller, non-damaging earthquakes that can be useful in estimating impacts of larger earthquakes. It also helps confirm the correct operation of the instruments by analyzing the smaller-amplitude triggers.

When one of the accelerometer channels exceeds the trigger threshold, the recorders save information within the data buffers. Data recording begins $10 \mathrm{~s}$ before the actual trigger time, continues until the trigger threshold is no longer exceeded, and ends with an additional $40 \mathrm{~s}$ of data. The saved files created by a triggered event are stored on memory cards to be retrieved and examined by HSAP staff. 



\subsection{Geology and Tectonic Analysis}

The Hanford Site lies within the Columbia Basin, an intermontane basin between the Cascade Range and the Rocky Mountains filled with Cenozoic volcanic rocks and sediments. This basin forms the northern part of the Columbia Plateau physiographic province (Fenneman 1931) and the Columbia River flood-basalt province (Reidel et al. 1989). In the central and western parts of the Columbia Basin, the Columbia River Basalt Group (CRBG) overlies Tertiary continental sedimentary rocks and is overlain by late Tertiary and Quaternary fluvial and glaciofluvial deposits (Campbell 1989; Reidel et al. 1989, 1994; DOE 1988). In the eastern part, little or no sediment separates the basalt and underlying crystalline basement, and a thin $(<10-\mathrm{m})$ veneer of eolian sediments overlies the basalt (Reidel et al. 1989, 1994).

The Columbia Basin has two structural subdivisions or subprovinces - the Yakima Fold Belt and the Palouse Slope. The Yakima Fold Belt includes the western and central parts of the Columbia Basin and is a series of anticlinal ridges and synclinal valleys with major thrust faults typically along the northern flanks (Figure 3.1) (Reidel and Fecht 1994a, 1994b). The Palouse Slope is the eastern part of the basin and is less deformed than the Yakima Fold Belt, with only a few faults and low-amplitude long-wavelength folds on an otherwise gently westward dipping paleoslope. Figure 3.2 shows north-south (B-B') and east-west (A-A') cross sections through the Columbia Basin based on surface mapping (Reidel and Fecht 1994a, 1994b), deep boreholes (Reidel et al. 1994), geophysical data (Rohay et al. 1985; DOE 1988), and magnetotelluric data obtained as part of BWIP (DOE 1988).

\subsection{Earthquake Stratigraphy}

Seismic studies at the Hanford Site have shown that the earthquake activity is related to crustal stratigraphy (large groupings of rock types) (Rohay et al. 1985; DOE 1988). The main geologic units important to earthquakes at the Hanford Site and the surrounding area are

- Miocene Columbia River Basalt Group

- Sub-basalt sediments of Paleocene, Eocene, Oligocene, and Early Miocene age

- Precambrian and Paleozoic cratonic basement

- Mesozoic accreted terranes forming the basement west of the craton margin.

\subsection{Geologic Structure Beneath the Monitored Area}

Between the late 1950s and the mid 1980s, deep boreholes were drilled for hydrocarbon exploration in the Columbia Basin. These boreholes provided accurate measurements of the physical properties of the CRBG and the pre-basalt sediments (Reidel et al. 1989, 1994), but the thickness of the sub-basalt sediments and nature of the basement are still poorly understood. Table 3.1, derived from Reidel et al. (1994), was developed for the geologic interpretation in this report. The thicknesses of these units are variable across the monitored area. Table 3.1 summarizes the approximate thickness at the borders of the monitored area. 


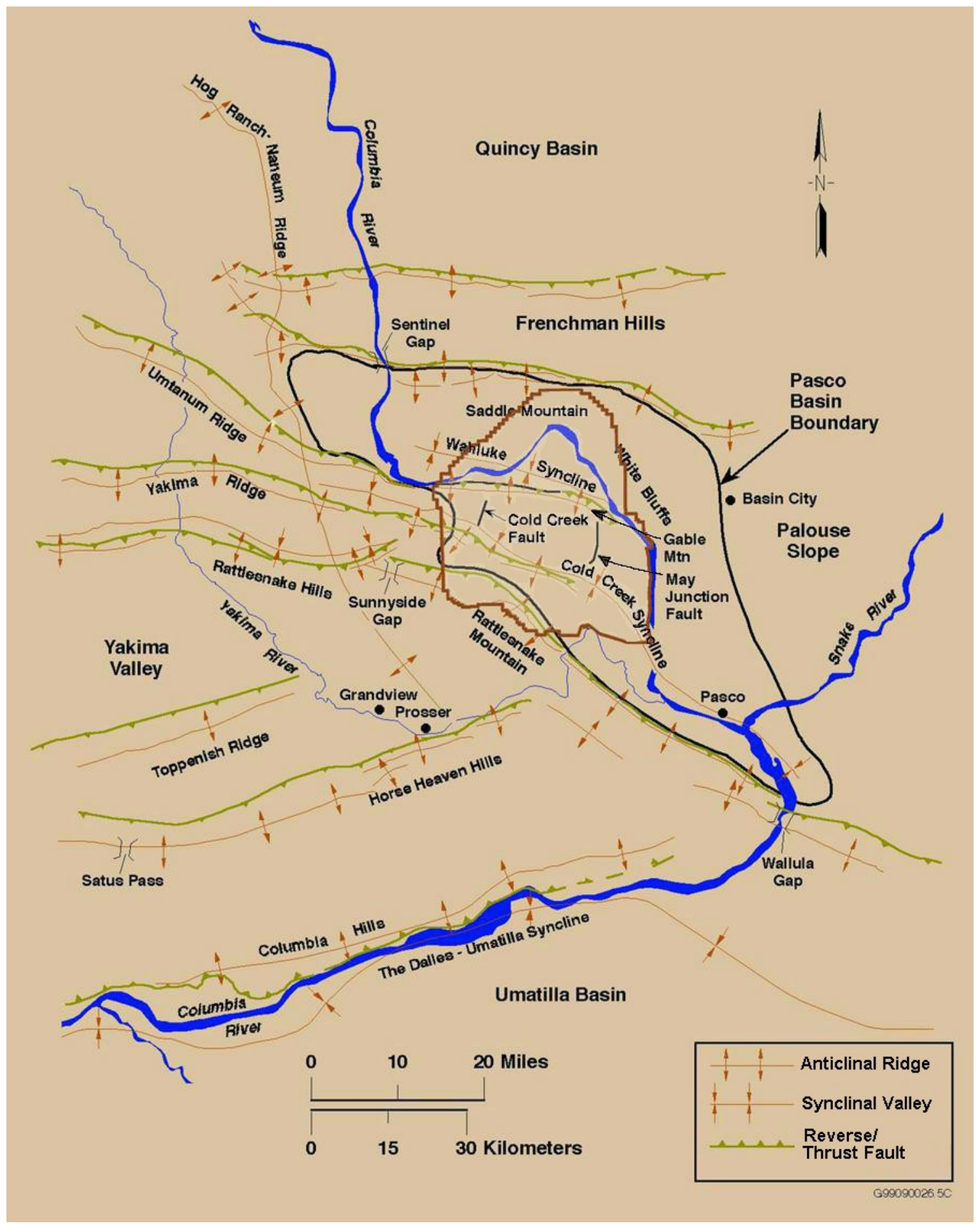

Figure 3.1. Physical and Structural Geology of the Hanford Site, Washington 

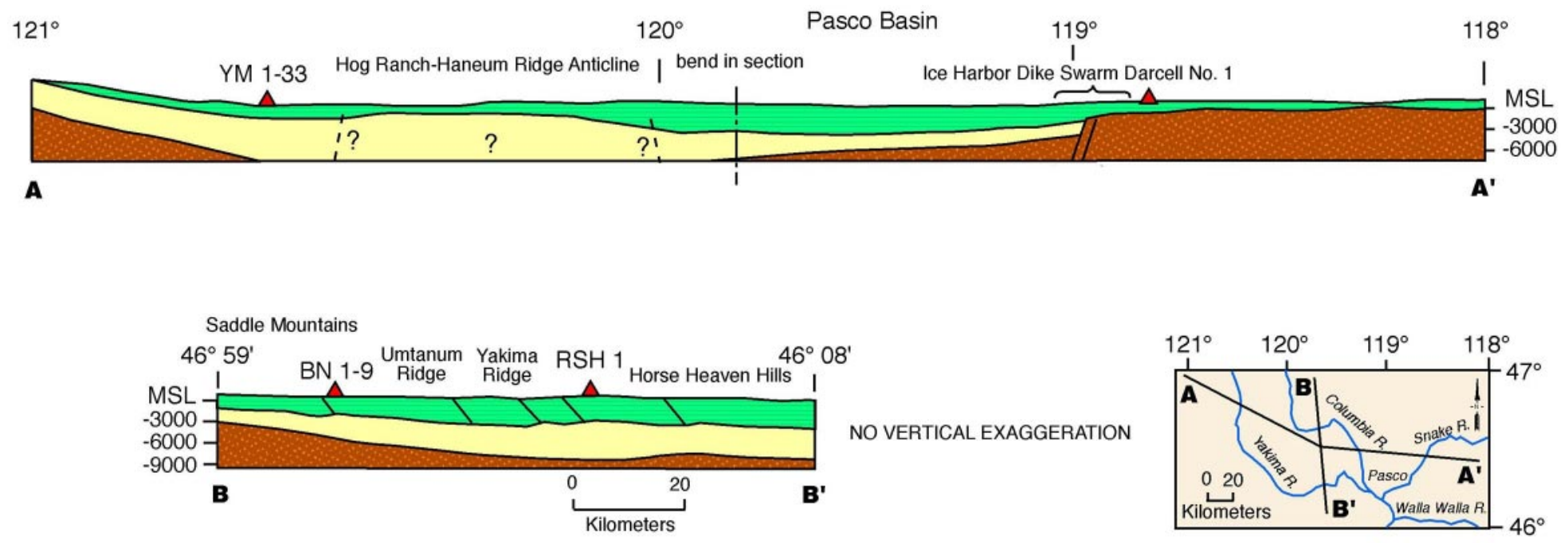

$\Delta$ Hydrocarbon exploration borehole $\quad \square$ Columbia River Basalt Group

$\square$ Tertiary sediments

Basement rock

G01010082.2

Figure 3.2. Geologic Cross Sections through the Columbia Basin (Reidel et al. 1994) 
Table 3.1. Thicknesses of Stratigraphic Units in the Monitoring Area (from Reidel et al. 1994)

\begin{tabular}{||l|c|c|c|c||}
\hline \multicolumn{1}{|c|}{ Stratigraphy } & North & South & East & West \\
\hline \hline Columbia River Basalt Group (includes suprabasalt sediments) & $3.0 \mathrm{~km}$ & $4.5 \mathrm{~km}$ & $2.2 \mathrm{~km}$ & $4.2 \mathrm{~km}$ \\
\hline Pre-basalt sediments & $3.0 \mathrm{~km}$ & $>4.5 \mathrm{~km}$ & 0 & $>6.0 \mathrm{~km}$ \\
\hline
\end{tabular}

The thickness of the basalt and the sub-basalt sediments varies as a result of different tectonic environments. The western edge of the North American craton (late Precambrian/Paleozoic continental margin and Precambrian craton) is located in the eastern portion of the monitored area (Reidel et al. 1994). The stratigraphy on the craton consists of CRBG overlying basement; the basement is continental crustal rock that underlies much of western North America. The stratigraphy west of the craton consists of 4 to $5 \mathrm{~km}$ of CRBG overlying up to $6 \mathrm{~km}$ of pre-basalt sediments. This in turn overlies accreted terranes of Mesozoic age. The area west of the craton was subsiding during the Eocene and Oligocene, accumulating great thickness of pre-CRBG sediments. Continued subsidence in this area during the Miocene resulted in thicker CRBG compared to that on the craton. Subsidence continues today but at a greatly reduced rate (Reidel et al. 1994).

\subsection{Tectonic Pattern}

Studies have concluded that earthquakes can occur in the following six different tectonic environments (earthquake sources) at the Hanford Site (Geomatrix 1996):

- Major Geologic Structures. Reverse/thrust faults in the CRBG associated with major anticlinal ridges such as Rattlesnake Mountain, Yakima Ridge, and Umtanum Ridge could produce some of the largest earthquakes.

- Secondary Faults. These faults are typically smaller (1 to $20 \mathrm{~km}$ in length) than the main reverse/ thrust faults that occur along the major anticlinal ridges (up to $100 \mathrm{~km}$ in length). Secondary faults can be segment boundaries (tear faults) and small faults of any orientation that formed along with the main structure.

- Swarm Areas. Small geographic areas not known to contain any geologic structures produce clusters of events (swarms), usually located in synclinal valleys. These clusters consist of a series of small shocks with no outstanding principal event. Swarms occur over a period of days or months, and the events may number into the hundreds and then quit, only to start again at a later date. This differs from the sequence of foreshocks, mainshock, and trailing-off aftershocks that have the same epicenter or are associated with the same fault system. In the past, swarms were thought to occur only in the CRBG. Most swarm areas are in the basalt, but swarm events also appear to occur in all geologic layers. However, typically a swarm event at a specific time is usually restricted to one layer. Seven earthquake swarm areas are recognized in the HSN area, but this list will be updated as new swarm areas develop. The Saddle Mountains, Wooded Island, Wahluke, Coyote Rapids, and Horse Heaven Hills swarm areas are typically active at one time or another during the year (see Figure 5.1 for a map of these swarm areas). The other earthquake swarm areas are active less frequently.

- Entire Columbia Basin. The entire basin, including the Hanford Site, could produce a "floating" earthquake. A floating earthquake is one that, for seismic design purposes, can happen anywhere in a tectonic province and is not associated with any known geologic structure. Seismic interpretation classifies it as a random event for purposes of seismic design and vibratory ground motion studies. 
- Basement Source Structures. Studies (Geomatrix 1996) suggest that major earthquakes can originate in tectonic structures in the basement. Because little is known about geologic structures in the basement beneath the Hanford Site, earthquakes cannot be directly tied to a mapped fault. Earthquakes occurring in the basement without known sources are treated as random events.

- Cascadia Subduction Zone. This source has been postulated to be capable of producing a magnitude 9 earthquake. Because this source is along the western boundary of Washington State and outside the HSN, the Cascadia subduction zone is not an earthquake source that is monitored at the Hanford Site, so subduction zone earthquakes are not reported here. Because any earthquake along the Cascadia subduction zone can have a significant impact on the Hanford Site or can be felt like the February 2001 Nisqually earthquake, UW monitors and reports on this earthquake source for the DOE. Ground motion from any moderate or larger Cascadia subduction zone earthquake is detected by Hanford SMAs and reported (see Section 5). 



\subsection{Earthquake Catalog Description}

An interactive program called XPED, developed at the University of Washington, is used to determine earthquake locations and magnitudes. This program reads seismogram data recorded by the Earthworm system and lets the user measure arrival times and durations from earthquakes. Arrival and duration times are used as input to the hypocenter routine within XPED to estimate locations and magnitudes of the seismic events. XPED results for local earthquakes (46-47 $7^{\circ}$ orth latitude, $119-120^{\circ}$ west longitude) are reported in Table 4.1. Other seismic events located in southeastern Washington, the Pacific Northwest, or outside the region also are evaluated, with results stored on the computer system; these results are not reported in this document. These other results sometimes are used as a check to confirm that the HSN is functioning properly (e.g., quality checks on data recording).

Beginning in January 2009 and continuing through March 2009 over 800 micro-earthquakes were recorded in the vicinity of Wooded Island. This includes multiple events that occurred within the recording periods of individual triggers; the precise number of events of the Wooded Island swarm will be determined later in the fiscal year when the triggers are further evaluated. Only those Wooded Island events with magnitude $\left(\mathrm{M}_{\mathrm{c}}\right)$ greater than or equal to 1.6 (including all events with magnitude greater than 2.0) have been completely evaluated and are included in Table 4.1. Table 4.1 also includes all events located outside the Wooded Island swarm area that were recorded within the Hanford monitored region.

\subsection{Coda-Length Magnitude}

Coda-length magnitude $\left(\mathrm{M}_{\mathrm{c}}\right)$, an estimate of local magnitude $\left(\mathrm{M}_{\mathrm{L}}\right)$ (Richter 1958), is calculated using a relationship developed for Washington State by Crosson (1972):

$$
\mathrm{M}_{\mathrm{c}}=2.82 \log (\mathrm{D})-2.46
$$

where $\mathrm{D}$ is the duration of the observed event. Many of the earthquakes have magnitude determinations that are very small $\left(\mathrm{M}_{\mathrm{c}}<0\right)$ and highly uncertain. In Section 4 , we define earthquakes as "minor" with magnitudes $\left(\mathrm{M}_{\mathrm{c}}\right)$ smaller than 1.0. Coda-length magnitudes for events classified as explosions are not reported because they are biased by a prominent surface wave that extends the apparent duration in a way inconsistent with coda-length measurement.

\subsection{Velocity Model}

XPED uses the crustal velocity model for eastern Washington given in Table 4.2. The model does not include a surficial layer for the Hanford or Ringold formations because most seismometer stations are sited on basalt. The crustal velocity model extends $38 \mathrm{~km}$ deep (to the mantle) and consists of six layers, each with uniform seismic velocity. The crustal velocity model was developed using available geologic information and calibrated from seismic data recorded from accurately located earthquake and blast events in eastern Washington. Time corrections (delays) are incorporated into the velocity model to account for significant deviations in station elevations or stations situated on sedimentary layers. Station delays also are determined empirically from accurately located earthquakes and blast events in the region. 
Table 4.1. Local Seismic Data, January 1 - March 31, 2009

\begin{tabular}{|c|c|c|c|c|c|c|c|c|c|c|c|c|c|}
\hline Event ID & Type & Date & Time & Lattitude & Longitude & Depth & Mag & NS/NP & Gap & Dmin & RMS & $\mathrm{Q}$ & Location \\
\hline 9010401313 & & 09/01/04 & 01:32:04.64 & $46 \mathrm{~N} 24.58$ & $119 W 16.78$ & 1.08 & 1.6 & $20 / 020$ & 86 & 2 & 0.06 & AA & $14 \mathrm{~km} \mathrm{~N}$ of Richland \\
\hline 9011317373 & $x$ & $09 / 01 / 13$ & $17: 37: 59.98$ & $46 N 09.22$ & $119 W 10.77$ & 1.05 & & $7 / 007$ & 154 & 20 & 0.06 & $\mathrm{AC}$ & $7 \mathrm{~km} \mathrm{SW}$ of Kennewick \\
\hline 9012620233 & & $09 / 01 / 26$ & $20: 24: 01.23$ & $46 \mathrm{~N} 24.72$ & 119W17.07 & 1.31 & 1.6 & $17 / 017$ & 85 & 1 & 0.1 & AA & 14 km N of Richland \\
\hline 9020609410 & & $09 / 02 / 06$ & 09:42:29.94 & $46 N 23.44$ & $119 W 27.13$ & 17.00 & 0.5 & $12 / 015$ & 97 & 2 & 0.06 & $A B$ & 17 km NW Richland \\
\hline 9021007405 & & $09 / 02 / 10$ & $07: 41: 21.10$ & $46 N 24.57$ & 119W16.78 & 1.34 & 2.4 & $22 / 022$ & 86 & 2 & 0.08 & AA & $14 \mathrm{~km} \mathrm{~N}$ of Richland \\
\hline 9021220362 & & $09 / 02 / 12$ & $20: 36: 53.91$ & $46 N 24.77$ & $119 W 17.22$ & 1.28 & 2.1 & $22 / 022$ & 84 & 1 & 0.08 & AA & $14 \mathrm{~km} \mathrm{~N}$ of Richland \\
\hline 9021606574 & & $09 / 02 / 16$ & 06:58:09.95 & $46 \mathrm{~N} 24.51$ & $119 W 17.28$ & 1.18 & 1.7 & $22 / 022$ & 85 & 2 & 0.07 & AA & $14 \mathrm{~km} \mathrm{~N}$ of Richland \\
\hline 9021607420 & & $09 / 02 / 16$ & $07: 43: 26.85$ & $46 N 24.55$ & $119 W 17.26$ & 1.29 & 2 & $16 / 016$ & 85 & 2 & 0.06 & AA & $14 \mathrm{~km} \mathrm{~N}$ of Richland \\
\hline 9021617562 & $\mathrm{P}$ & $09 / 02 / 16$ & $17: 56: 33.20$ & $46 N 01.78$ & $119 W 54.89$ & 0.03 & & $8 / 008$ & 91 & 15 & 0.14 & $\mathrm{BC}$ & $23 \mathrm{~km}$ SSW of Prosser \\
\hline 9022116510 & & $09 / 02 / 21$ & $16: 52: 26.00$ & $46 N 24.45$ & 119W17.31 & 1.79 & 2.9 & $20 / 025$ & 85 & 2 & 0.09 & AA & 14 km N of Richland \\
\hline 9022301273 & & $09 / 02 / 23$ & 01:28:00.33 & $46 \mathrm{~N} 24.63$ & $119 W 16.72$ & 1.39 & 1.6 & $23 / 023$ & 86 & 2 & 0.08 & AA & $14 \mathrm{~km} \mathrm{~N}$ of Richland \\
\hline 9022718202 & & $09 / 02 / 27$ & $18: 20: 51.65$ & 46 N37.09 & $119 W 17.87$ & 15.84 & 0.1 & $15 / 016$ & 69 & 7 & 0.08 & AA & $25 \mathrm{~km} \mathrm{SSW}$ of Othello \\
\hline 9030717272 & & $09 / 03 / 07$ & $17: 27: 53.02$ & $46 \mathrm{~N} 24.22$ & 119W16.87 & 0.41 & 2.1 & $21 / 021$ & 87 & 1 & 0.05 & AA & $14 \mathrm{~km} \mathrm{~N}$ of Richland \\
\hline 9030717331 & & $09 / 03 / 07$ & $17: 33: 37.07$ & $46 N 23.96$ & $119 W 16.73$ & 0.4 & 2.1 & $19 / 019$ & 108 & 1 & 0.08 & $A B$ & $14 \mathrm{~km} \mathrm{~N}$ of Richland \\
\hline 9030809290 & & 09/03/08 & 09:30:04.25 & $46 \mathrm{~N} 24.56$ & $119 W 16.73$ & 1.54 & 2.4 & $18 / 021$ & 86 & 2 & 0.09 & AA & $14 \mathrm{~km} \mathrm{~N}$ of Richland \\
\hline 9030814411 & & $09 / 03 / 08$ & 14:41:41.20 & $46 \mathrm{~N} 12.12$ & $119 W 36.81$ & 8.16 & 0.1 & $16 / 021$ & 106 & 5 & 0.11 & $A B$ & $12 \mathrm{~km} \mathrm{E}$ of Prosser \\
\hline 9030815414 & & $09 / 03 / 08$ & $15: 42: 13.16$ & $46 \mathrm{~N} 24.26$ & $119 W 16.39$ & 0.43 & 2.1 & $19 / 022$ & 89 & 1 & 0.1 & AA & $14 \mathrm{~km} \mathrm{~N}$ of Richland \\
\hline 9030905271 & & $09 / 03 / 09$ & $05: 28: 36.45$ & $46 \mathrm{~N} 24.53$ & $119 W 16.49$ & 1.49 & 2.1 & $19 / 022$ & 87 & 2 & 0.09 & AA & $14 \mathrm{~km} \mathrm{~N}$ of Richland \\
\hline 9031021555 & & $09 / 03 / 10$ & 21:56:15.94 & $46 \mathrm{~N} 24.36$ & $119 W 16.84$ & 0.42 & 2.1 & $19 / 020$ & 87 & 2 & 0.12 & AA & $14 \mathrm{~km} \mathrm{~N}$ of Richland \\
\hline 9031023001 & & $09 / 03 / 10$ & 23:00:41.52 & $46 \mathrm{~N} 24.09$ & $119 W 16.80$ & 1.34 & 1.9 & $17 / 020$ & 106 & 1 & 0.07 & $A B$ & $14 \mathrm{~km} \mathrm{~N}$ of Richland \\
\hline 9031203364 & & $09 / 03 / 12$ & 03:37:14.40 & $46 N 23.98$ & $119 W 16.69$ & 0.38 & 1.7 & $19 / 019$ & 110 & 1 & 0.06 & $A B$ & $14 \mathrm{~km} \mathrm{~N}$ of Richland \\
\hline 9031205464 & & $09 / 03 / 12$ & 05:47:14.24 & $46 \mathrm{~N} 24.02$ & $119 W 16.73$ & 1.56 & 2 & $14 / 018$ & 108 & 1 & 0.1 & $A B$ & $14 \mathrm{~km} \mathrm{~N}$ of Richland \\
\hline 9031217392 & & $09 / 03 / 12$ & $17: 39: 54.60$ & $46 N 24.38$ & $119 W 16.57$ & 1.05 & 2.8 & $19 / 022$ & 88 & 2 & 0.12 & AA & $14 \mathrm{~km} \mathrm{~N}$ of Richland \\
\hline 9031302093 & & $09 / 03 / 13$ & 02:10:04.82 & $46 N 24.36$ & $119 W 16.26$ & 1.21 & 2.1 & $20 / 021$ & 89 & 2 & 0.09 & AA & $14 \mathrm{~km} \mathrm{~N}$ of Richland \\
\hline 9031315370 & & 09/03/13 & 15:38:31.51 & $46 N 23.83$ & $119 W 16.57$ & 0.05 & 1.8 & $18 / 021$ & 89 & 1 & 0.08 & AA & $14 \mathrm{~km} \mathrm{~N}$ of Richland \\
\hline 9031319252 & & $09 / 03 / 13$ & 19:25:52.31 & $46 \mathrm{~N} 24.00$ & 119W16.59 & 0.42 & 2.3 & $16 / 019$ & 115 & 1 & 0.09 & $A B$ & $14 \mathrm{~km} \mathrm{~N}$ of Richland \\
\hline 9031511082 & & $09 / 03 / 15$ & $11: 08: 48.58$ & $46 \mathrm{~N} 24.21$ & $119 W 16.50$ & 0.23 & 1.6 & $15 / 015$ & 95 & 3 & 0.08 & $A B$ & $14 \mathrm{~km} \mathrm{~N}$ of Richland \\
\hline 9031515533 & & $09 / 03 / 15$ & $15: 54: 05.37$ & $46 N 24.12$ & $119 W 17.10$ & 1.03 & 1.6 & $16 / 016$ & 93 & 3 & 0.1 & $A B$ & $14 \mathrm{~km} \mathrm{~N}$ of Richland \\
\hline 9031517574 & & 09/03/15 & 17:58:05.65 & $46 N 24.09$ & $119 W 16.88$ & 0.31 & 1.6 & $15 / 015$ & 94 & 3 & 0.07 & $A B$ & $14 \mathrm{~km} \mathrm{~N}$ of Richland \\
\hline 9031605420 & & $09 / 03 / 16$ & 05:42:31.89 & $46 N 23.91$ & 119W16.54 & 0.29 & 1.7 & $16 / 016$ & 95 & 3 & 0.1 & $A B$ & $14 \mathrm{~km} \mathrm{~N}$ of Richland \\
\hline 9031607305 & & $09 / 03 / 16$ & 07:31:19.59 & $46 N 23.90$ & $119 W 17.03$ & 1.65 & 2.5 & $16 / 016$ & 94 & 3 & 0.08 & $\mathrm{AB}$ & $14 \mathrm{~km} \mathrm{~N}$ of Richland \\
\hline 9031705030 & & $09 / 03 / 17$ & 05:04:29.04 & $46 N 23.97$ & 119W16.61 & 1.07 & 2.3 & $23 / 023$ & 89 & 1 & 0.07 & AA & $14 \mathrm{~km} \mathrm{~N}$ of Richland \\
\hline 9031806390 & & $09 / 03 / 18$ & 06:40:31.91 & $46 N 24.37$ & $119 W 16.60$ & 1.17 & 2.9 & $17 / 017$ & 115 & 2 & 0.05 & $A B$ & $14 \mathrm{~km} \mathrm{~N}$ of Richland \\
\hline 9031806474 & & 09/03/18 & 06:48:48.24 & $46 N 24.32$ & $119 W 16.10$ & 1.87 & 2.8 & $17 / 017$ & 133 & 2 & 0.09 & $A B$ & $14 \mathrm{~km} \mathrm{~N}$ of Richland \\
\hline
\end{tabular}


Table 4.1. continued

\begin{tabular}{|c|c|c|c|c|c|c|c|c|c|c|c|c|c|}
\hline Event ID & Type & Date & Time & Lattitude & Longitude & Depth & Mag & NS/NP & Gap & Dmin & RMS & Q & Location \\
\hline 9031814144 & & $09 / 03 / 18$ & $14: 15: 10.89$ & $46 N 24.51$ & 119W16.55 & 1.28 & 1.6 & $13 / 015$ & 116 & 2 & 0.09 & $A B$ & $14 \mathrm{~km} \mathrm{~N}$ of Richland \\
\hline 9031814152 & & 09/03/18 & 14:16:19.44 & $46 \mathrm{~N} 24.56$ & 119W16.49 & 0.36 & 1.6 & $4 / 006$ & 118 & 2 & 0.06 & $A D$ & $14 \mathrm{~km} \mathrm{~N}$ of Richland \\
\hline 9031814170 & & $09 / 03 / 18$ & $14: 20: 07.95$ & $46 N 24.34$ & 119W16.44 & 0.39 & 1.8 & $15 / 016$ & 121 & 2 & 0.11 & $A B$ & $14 \mathrm{~km} \mathrm{~N}$ of Richland \\
\hline 9031906250 & & 09/03/19 & $06: 26: 27.43$ & $46 N 24.80$ & $119 W 17.52$ & 0.41 & 1.9 & $23 / 023$ & 83 & 1 & 0.1 & AA & $14 \mathrm{~km} \mathrm{~N}$ of Richland \\
\hline 9032110111 & & $09 / 03 / 21$ & 10:11:37.61 & $46 N 51.98$ & $119 W 31.41$ & 16.73 & 2.3 & $38 / 045$ & 45 & 9 & 0.13 & AA & $28 \mathrm{~km} \mathrm{~W}$ of Othello \\
\hline 9032318165 & & 09/03/23 & $18: 17: 24.86$ & $46 N 23.63$ & 119W16.08 & 1.03 & 2 & $18 / 020$ & 92 & 0 & 0.06 & $A B$ & $14 \mathrm{~km} \mathrm{~N}$ of Richland \\
\hline 9032410511 & & $09 / 03 / 24$ & 10:52:19.89 & $46 N 23.59$ & $119 W 18.00$ & 1.61 & 1.6 & $11 / 013$ & 114 & 2 & 0.06 & $A B$ & $14 \mathrm{~km} \mathrm{~N}$ of Richland \\
\hline 9032411132 & & $09 / 03 / 24$ & 11:13:53.10 & $46 N 23.68$ & 119W16.38 & 0.94 & 1.6 & $20 / 020$ & 91 & 0 & 0.07 & $A B$ & $14 \mathrm{~km} \mathrm{~N}$ of Richland \\
\hline 9032523021 & & $09 / 03 / 25$ & 23:02:42.44 & $46 N 23.45$ & $119 W 16.86$ & 0.37 & 1.9 & $18 / 023$ & 82 & 0 & 0.05 & AA & $14 \mathrm{~km} \mathrm{~N}$ of Richland \\
\hline 9032607254 & & $09 / 03 / 26$ & 07:26:10.69 & $46 N 23.56$ & $119 W 17.25$ & 0.78 & 1.6 & $11 / 014$ & 104 & 1 & 0.04 & $A B$ & $14 \mathrm{~km} \mathrm{~N}$ of Richland \\
\hline 9032609184 & & $09 / 03 / 26$ & 09:19:10.07 & $46 N 23.62$ & 119W17.08 & 1.36 & 1.7 & $16 / 021$ & 92 & 1 & 0.08 & $A B$ & $14 \mathrm{~km} \mathrm{~N}$ of Richland \\
\hline 9033008113 & & $09 / 03 / 30$ & 08:11:58.09 & $46 \mathrm{~N} 24.01$ & 119W16.72 & 1.37 & 1.6 & $18 / 020$ & 88 & 1 & 0.07 & AA & $14 \mathrm{~km} \mathrm{~N}$ of Richland \\
\hline 9033104335 & & 09/03/31 & 04:34:23.20 & $46 N 23.82$ & $119 W 18.25$ & 0.3 & 1.7 & $17 / 019$ & 77 & 2 & 0.08 & AA & $14 \mathrm{~km} \mathrm{~N}$ of Richland \\
\hline 9033110244 & & 09/03/31 & $10: 25: 10.86$ & $46 N 24.55$ & 119W18.14 & 0.05 & 1.6 & $14 / 014$ & 83 & 2 & 0.07 & AA & $14 \mathrm{~km} \mathrm{~N}$ of Richland \\
\hline
\end{tabular}




\section{Explanation of Table 4.1}

Event ID: The Earthworm recording system creates the identification number. XPED uses the year, month, day, and time to create a unique number for each event.

Type: $\quad$ P is Probable Blast; X is Confirmed Blast; F is Felt Earthquake; blank is local earthquake.

Date: The year and date in Universal Time Coordinated (UTC). UTC is used throughout this report unless otherwise indicated.

Time: $\quad$ The origin time of the earthquake given in Coordinated Universal Time (UTC). To covert UTC to Pacific Standard Time, subtract eight hours; to Pacific Daylight Time, subtract seven hours.

Latitude: $\quad$ North latitude, in degrees and minutes, of the earthquake epicenter.

Longitude: West longitude, in degrees and minutes, of the earthquake epicenter.

Depth: $\quad$ The depth of the earthquake in kilometers $(\mathrm{km})$.

Mag: $\quad$ The magnitude is expressed as coda-length magnitude $\mathrm{M}_{\mathrm{c}}$, an estimate of local magnitude $\mathrm{M}_{\mathrm{L}}$ (Richter 1958). If magnitude is blank, a determination was not made.

NS/NP: $\quad$ Number of stations/number of phases used in the solutions.

Gap: $\quad$ Azimuthal gap; the largest angle (relative to the epicenter) containing no stations.

DMIN: $\quad$ The distance from the earthquake epicenter to the closest station.

RMS: $\quad$ The root-mean-square residual (observed arrival times minus the predicted arrival times) at all stations used to locate the earthquake. It is useful as a measure of quality of the solution only when five or more welldistributed stations are used in the solution. Good solutions are normally characterized by RMS values of less than about $0.3 \mathrm{~s}$.

Q: Quality factors; indicate the general reliability of the solution/location (A is best quality, D is worst). See Section 3.3 of this report, "Quality Factors."

\subsection{Quality Factors (Q)}

XPED assigns a two-letter Quality factor (Table 4.1) that indicates the general reliability of the solution (A is best quality, $\mathbf{D}$ is worst). Similar quality factors are used by the USGS for events located with the computer program HYPO71. The first letter of the quality code is a measure of the hypocenter quality based primarily on arrival time residuals. For example: Quality A requires a root-mean-square residual (RMS) less than $0.15 \mathrm{~s}$, while a RMS of $0.5 \mathrm{~s}$ or more is $\mathbf{D}$ quality (other estimates of the location uncertainty also affect this quality parameter). The second letter of the quality code is related to the spatial distribution of stations that contribute to the event location, including the number of stations (NS), the number of p-wave and s-wave phases (NP), the largest gap in event-station azimuth distribution (GAP), and the closest distance from the epicenter to a station (DMIN). Quality A requires a solution with $\mathbf{N P}>8, \mathbf{G A P}<90^{\circ}$, and $\mathbf{D M I N}<5 \mathrm{~km}$ (or the hypocenter depth if it is greater than $5 \mathrm{~km}$ ). If $\mathbf{N P} \leq 5$, GAP $>180^{\circ}$, or DMIN $>50 \mathrm{~km}$, the solution is assigned Quality $\mathbf{D}$.

Uncertainties associated with estimated depths depend upon the number of stations and number of phase measurements (NS/NP) utilized in the XPED calculation. Generally speaking, if the number of phases exceeds 10 measurements, the depth estimate is considered to be reliable. In this case the second letter in the quality evaluation is either "A" or "B" (cf. Table 4.1). For example, the number of phase measurements from earthquakes ultimately classified as "deep" events typically falls within the 10-20 measurement range; these depth estimates are considered reliable. However, the number of phase measurements from earthquakes classified as "shallow" or "intermediate" may be less than 10 readings; 
in this case the depth estimate is less certain and the event could be classified as occurring in the CRBG or pre-basalt layers.

Table 4.2. Crustal Velocity Model for Eastern Washington (from Rohay et al. 1985)

\begin{tabular}{||c|l|c||}
\hline $\begin{array}{c}\text { Depth to Top of } \\
\text { Velocity Layer }(\mathrm{km})\end{array}$ & \multicolumn{1}{c||}{ Layer } & $\begin{array}{c}\text { Velocity } \\
(\mathrm{km} / \mathrm{s})\end{array}$ \\
\hline \hline 0.0 & Saddle Mountains and Wanapum Basalts and intercalated Ellensburg Formation & 3.7 \\
\hline 0.4 & Grande Ronde Basalt and pre-basalt sediments & 5.2 \\
\hline 8.5 & Basement, Layer 1 & 6.1 \\
\hline 13.0 & Basement, Layer 2 & 6.4 \\
\hline 23.0 & Sub-basement & 7.1 \\
\hline 38.0 & Mantle & 7.9 \\
\hline
\end{tabular}





\subsection{Seismic Activity - Second Quarter FY 2009}

\subsection{Summary}

The Hanford Seismic Network recorded over 800 local earthquakes during the second quarter of FY 2009. Nearly all of these earthquakes were detected in the vicinity of Wooded Island, located about eight miles north of Richland just west of the Columbia River. Most of the events were considered minor with 19 events with magnitude $\left(M_{c}\right)$ estimated in the 2.0-2.9 range. The estimated depths of the Wooded Island events are shallow (averaging less than $1.0 \mathrm{~km}$ deep) with a maximum depth estimated at $1.9 \mathrm{~km}$. This places the Wooded Island events within the Columbia River Basalt Group (CRBG).

Outside of the Wooded Island swarm, four earthquakes were recorded. Three earthquakes were considered minor with magnitudes $\left(\mathrm{M}_{\mathrm{c}}\right)$ less than 1.0 and one event registered $2.3 \mathrm{M}_{\mathrm{c}}$. One earthquake was located at intermediate depth (between 4 and $9 \mathrm{~km}$, most likely in the pre-basalt sediments) and three earthquakes at depths greater than $9 \mathrm{~km}$, within the basement. Geographically, two earthquakes were located in known swarm areas and two earthquakes were classified as random events.

Most of the earthquakes at the Hanford Site have been located at shallow depths with the next greatest number of earthquakes located in the basement. Intermediate depth events have historically shown the fewest number of earthquakes.

\subsection{Second Quarter FY 2009 Earthquakes}

During the second quarter of FY 2009 the HSN recorded 999 triggers, which included over 800 events located in the southeast Washington area and an additional 79 regional and teleseismic events. For this report, 806 events were estimated as being located in the Hanford monitoring zone and included two blast events (Table 4.1). As discussed in Chapter 4.0, over 800 events were located in the Wooded Island swarm; only the larger magnitude $\left(\mathrm{M}_{\mathrm{c}}\right)$ events (above 1.6) are listed in Table 4.1.

The depth distribution and geographic pattern of the 804 earthquakes that occurred in the Hanford area are classified in Table 5.1 and Table 5.2. Epicenters of the Table 4.1 events are shown in Figure 5.1; the depths of these events are shown in Figure 5.2 projected into the 119W30 Longitude cross section.

Table 5.1. Depth Distribution of Earthquakes for FY 2009

\begin{tabular}{||l|c|c|c|c|c||}
\hline \multicolumn{1}{|c|}{ Category } & First Quarter & Second Quarter & Third Quarter & Fourth Quarter & FY 2009 \\
\hline \hline Shallow (0-4 km deep) & 2 & 800 & & & $802(98 \%)$ \\
\hline Intermediate (4-9 km deep) & 5 & 1 & & & $6(1 \%)$ \\
\hline Deep (greater than 9 km deep) & 3 & 3 & & & $6(1 \%)$ \\
\hline Total & 10 & 804 & & & $814(100 \%)$ \\
\hline
\end{tabular}


Table 5.2. Earthquake Locations for FY 2009

\begin{tabular}{|c|c|c|c|c|c|c|}
\hline & Seismic Sources & $\begin{array}{l}\text { First Quarter } \\
10 / 01-12 / 31\end{array}$ & $\begin{array}{c}\text { Second Quarter } \\
1 / 01-3 / 31\end{array}$ & $\begin{array}{c}\text { Third Quarter } \\
\text { 4/01-6/30 }\end{array}$ & $\begin{array}{c}\text { Fourth Quarter } \\
7 / 01-9 / 30\end{array}$ & FY 2009 \\
\hline \multicolumn{7}{|c|}{ Geologic Structure } \\
\hline \multirow{9}{*}{$\begin{array}{l}\text { Swarm } \\
\text { Areas }\end{array}$} & Frenchman Hills & & & & & \\
\hline & $\begin{array}{l}\text { Saddle Mountains/ } \\
\text { Royal Slope }\end{array}$ & & 1 & & & 1 \\
\hline & Wahluke Slope & & & & & \\
\hline & Coyote Rapids & 2 & & & & 2 \\
\hline & Wye & & 800 & & & 800 \\
\hline & Cold Creek & & & & & \\
\hline & Rattlesnake Mountain. & 2 & & & & 2 \\
\hline & Horse Heaven Hills & & 1 & & & 1 \\
\hline & Total for swarm areas & 4 & 802 & & & $806(99 \%)$ \\
\hline \multicolumn{2}{|c|}{ Random Events } & 6 & 2 & & & $8(1 \%)$ \\
\hline \multicolumn{2}{|c|}{ Total for all earthquakes } & 10 & 804 & & & 814 \\
\hline
\end{tabular}

\subsubsection{Location and Depth of Earthquakes}

During the second quarter of FY 2009, 802 events occurred in swarm areas and 2 events were classified as random. Small geographic areas not known to contain any geologic structures produce clusters of events (swarms), usually located in synclinal valleys. Swarms were generally thought to occur only at relatively shallow depths within the CRBG, however, in recent years swarms have been recorded at deeper locations, for example, within the Horse Heaven Hills (Rohay et al, 2008a).

\subsubsection{Major Anticlinal Ridges}

No earthquakes were associated within the major geologic structures in the area surrounding the Hanford Site for the second quarter of FY 2009.

\subsubsection{Earthquake Swarm Areas}

Eight-hundred and two (802) earthquakes were characterized as swarm events in the second quarter of FY 2009.

\section{Saddle Mountain Swarm Area}

A magnitude 2.3 event was recorded on March 21 and located at depth $16.7 \mathrm{~km}$ within the basement.

\section{Horse Heaven Hills Slope Swarm Area}

A minor event was recorded on March 8 and located at depth $8.2 \mathrm{~km}$, presumably within the prebasalt sediments. 


\section{Wye Swarm Area}

As previously discussed, beginning in January 2009 and continuing through March 2009 approximately 800 earthquakes were recorded in the vicinity of Wooded Island. Only those Wooded Island events with magnitude $\left(\mathrm{M}_{\mathrm{c}}\right)$ greater than or equal to 1.6 (including all events with magnitude greater than 2.0) are included in Table 4.1.

The Wooded Island swarm is located about eight miles north of Richland west of the Columbia River about halfway between Hanford's 300 Area and Energy Northwest. Most of the events are considered minor with 19 events with magnitude $\left(\mathrm{M}_{\mathrm{c}}\right)$ in the 2.0-2.9 range. The estimated depths of the Wooded Island events are shallow (averaging less than $1.0 \mathrm{~km}$ deep) with a maximum depth estimated at $1.9 \mathrm{~km}$. This places the Wooded Island events within the Columbia River Basalt Group (CRBG).

The low magnitude of the Wooded Island events has made them undetectable to all but local area residents. The Hanford SMA network was triggered numerous times by these events and the SMA recordings are discussed in section 6.0. Some Hanford employees working within a few miles of the swarm area and individuals living directly across the Columbia River from the swarm center have reported feeling many of the larger magnitude events.

The swarming is likely due to pressure that has built up, cracking the brittle basalt layers within the Columbia River Basalt Formation (CRBG). Similar earthquake swarms have been recorded near this same location in 1970, 1975 and 1988. Prior to the 1970s, swarming may have occurred, but equipment was not in place to record those events.

Quakes of this limited magnitude do not pose a risk to Hanford cleanup efforts or waste storage facilities. Since swarms of the past did not intensify in magnitude, seismologists do not expect that these events will increase in intensity. However, PNNL will continue to monitor the activity. 


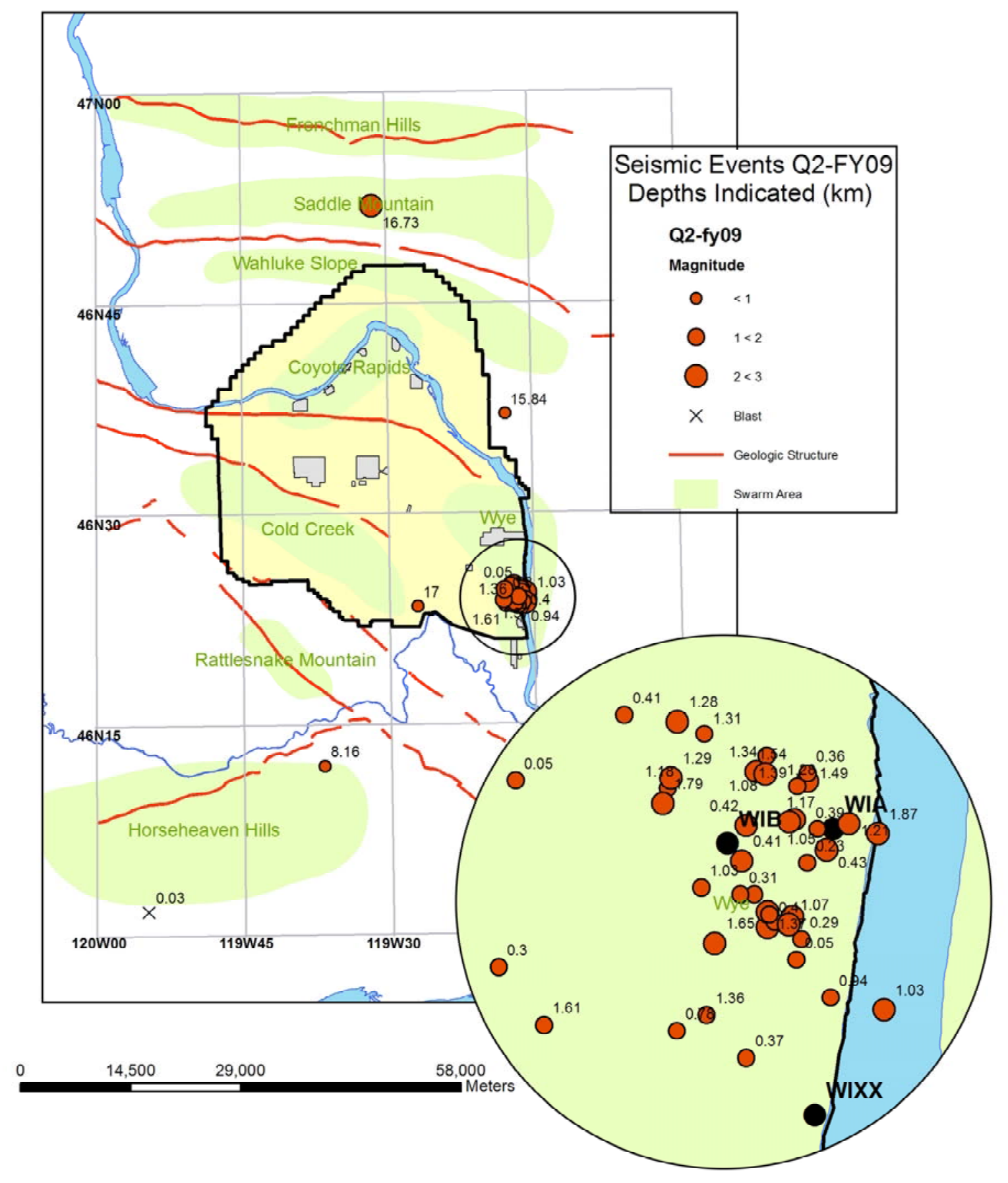

Figure 5.1. Earthquakes Occurring in the Hanford Monitoring Area Between January 1, 2009 and March 31, 2009 (second quarter) 

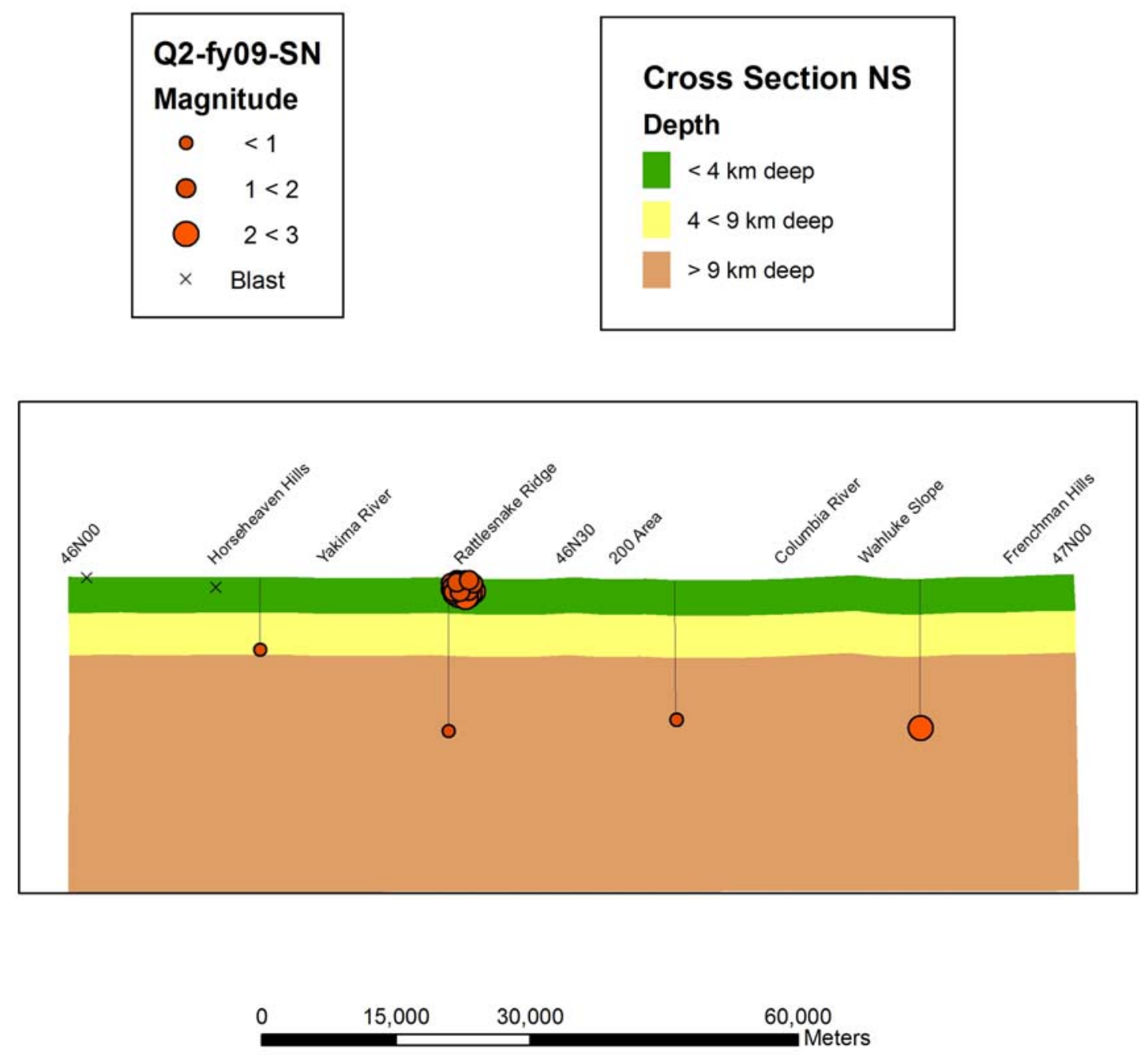

Figure 5.2. Cross-Sectional Depiction (along 119W30 longitude) of Earthquakes Occurring in the Hanford Monitoring Area between January 1, 2009 and March 31, 2009 (second quarter)

\subsubsection{Random or Floating Events}

A minor event occurred on February 6 with epicenter located approximately $2 \mathrm{~km}$ north of the southern Hanford Site boundary at depth $17.0 \mathrm{~km}$ within the basement unit. A minor event occurred on February 27 with epicenter located just east of the Hanford Site in Franklin County at depth $15.8 \mathrm{~km}$ within the basement unit. 



\subsection{Strong Motion Accelerometer Operations}

The Hanford SMA network has been in continuous operation since November 20, 1998. Initially, the threshold used in the SMA network was $0.1 \% \mathrm{~g}$. In 2006, the trigger threshold was reduced to $0.02 \% \mathrm{~g}$ when new instruments with greater storage capacity were installed. The lower trigger threshold saves the ground motion recordings for smaller, non-damaging earthquakes that can be useful in estimating the ground motion expected from larger earthquakes, and to confirm correct operation of the instruments by analyzing the smaller-amplitude triggers (see Section 2.2).

\subsection{Second Quarter FY 2009 Triggers of the Hanford SMA Network}

The Hanford SMA network was triggered numerous times by the Wooded Island swarm events. The 300 Area SMA recorded 151 triggers of which 19 indicated multiple seismic events occurring within the recording period. The 400 Area SMA recorded 69 triggers of which 6 indicated multiple seismic events. The 200 West, 200 East, and 100 K Area SMA's did not record triggers from the Wooded Island events.

The February 21 event $\left(2.9 \mathrm{M}_{\mathrm{c}}\right.$ at depth $\left.1.8 \mathrm{~km}\right)$ triggered the 300 Area SMA (located approximately $5.6 \mathrm{~km}$ south of the epicenter) and the 400 Area SMA (located approximately $6.2 \mathrm{~km}$ west of the epicenter). This event caused peak vertical accelerations of $0.84 \% \mathrm{~g}$ at the 300 Area SMA and $0.66 \% \mathrm{~g}$ at the 400 Area SMA. The acceleration values were approximately 2-3 times lower that the reportable action level for Hanford facilities ( $2 \% \mathrm{~g})$ and no action was required. Table 6.1 lists the maximal accelerations recorded at the 300 Area and 400 Area SMA's for the highest magnitude $\left(\mathrm{M}_{c}\right)$ events within the Wooded Island swarm. These are the largest recorded accelerations from a local earthquake at the Hanford SMA's since installation in 1998. Figure 6.1 depicts the acceleration record for the February 21 event at the 300 Area SMA.

Table 6.1. Maximum Accelerations from the Highest Magnitude $\left(M_{c}\right)$ Wooded Island Earthquake Swarm Events

\begin{tabular}{|l|l|l|l|c|c|c|c|c|}
\hline \multicolumn{2}{|l|}{ SMA Unit } & \multicolumn{3}{|c|}{$300 \mathrm{~A}$} & \multicolumn{3}{c|}{$400 \mathrm{~A}$} \\
\hline Date & Time & $\begin{array}{c}\text { Magnitude } \\
\left(\mathrm{M}_{\mathrm{c}}\right)\end{array}$ & $\begin{array}{c}\% \mathrm{~g} \\
\text { Horizontal }\end{array}$ & $\begin{array}{c}\% \mathrm{~g} \\
\text { Vertical }\end{array}$ & $\begin{array}{c}\text { Distance } \\
\text { from event, } \\
\mathrm{km}\end{array}$ & $\begin{array}{c}\% \mathrm{~g} \\
\text { Horizontal }\end{array}$ & $\begin{array}{c}\text { \% g } \\
\text { Vertical } \\
\text { from event, } \\
\mathrm{km}\end{array}$ \\
\hline $2 / 21 / 2009$ & $16: 51$ & 2.9 & 0.84 & 0.25 & 5.6 & 0.66 & 0.30 & 6.2 \\
\hline $3 / 12 / 2009$ & $17: 39$ & 2.8 & 0.54 & 0.32 & 5.4 & 0.13 & 0.10 & 7.1 \\
\hline $3 / 18 / 2009$ & $06: 39$ & 2.9 & 0.56 & 0.36 & 5.4 & 0.25 & 0.13 & 7.0 \\
\hline $3 / 18 / 2009$ & $06: 47$ & 2.8 & 0.53 & 0.43 & 5.3 & 0.11 & 0.07 & 7.6 \\
\hline
\end{tabular}




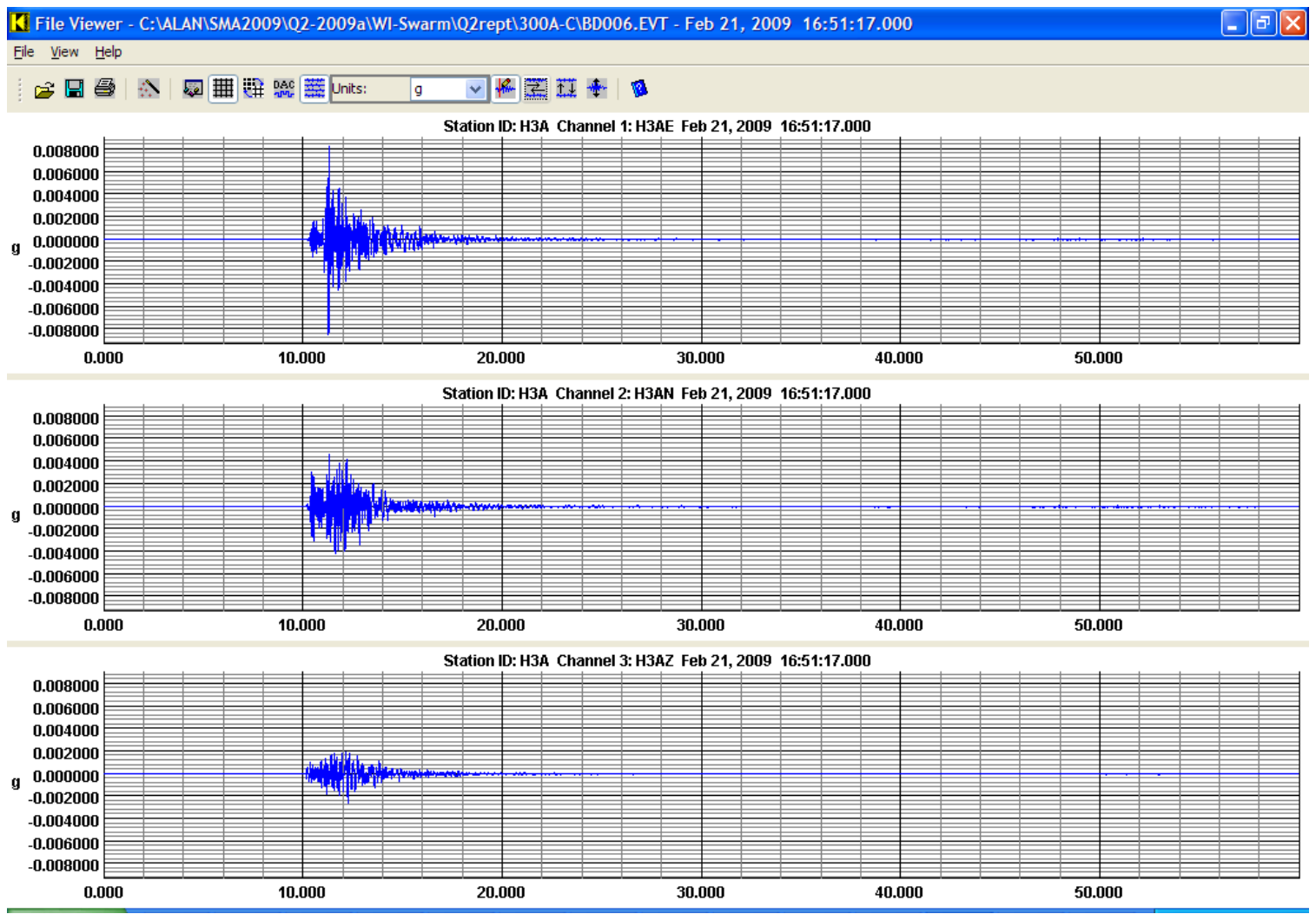

Figure 6.1. Acceleration Records from the 02/21/2009 magnitude 2.9 Swarm Event at the 300 Area SMA

The other SMA triggers associated with the Wooded Island swarm events were very similar to the response to the February 21 event but showed lower ground acceleration values. No action was required for those triggers.

On January 30, 2009 an earthquake was reported with epicenter near Poulsbo, Washington in Puget Sound with magnitude $\left(\mathrm{M}_{\mathrm{c}}\right) 4.5$ and depth $58 \mathrm{~km}$. The $100 \mathrm{~K}, 200 \mathrm{West}$, and 200 East Area SMA's recorded triggers for this event with maximum horizontal acceleration $0.02 \% \mathrm{~g}$ and maximum vertical acceleration $0.01 \% \mathrm{~g}$. The SMA trigger threshold of $0.02 \% \mathrm{~g}$ was barely exceeded and no action was required. The acceleration record at the $100 \mathrm{~K}$ Area SMA is shown in Figure 6.2. 


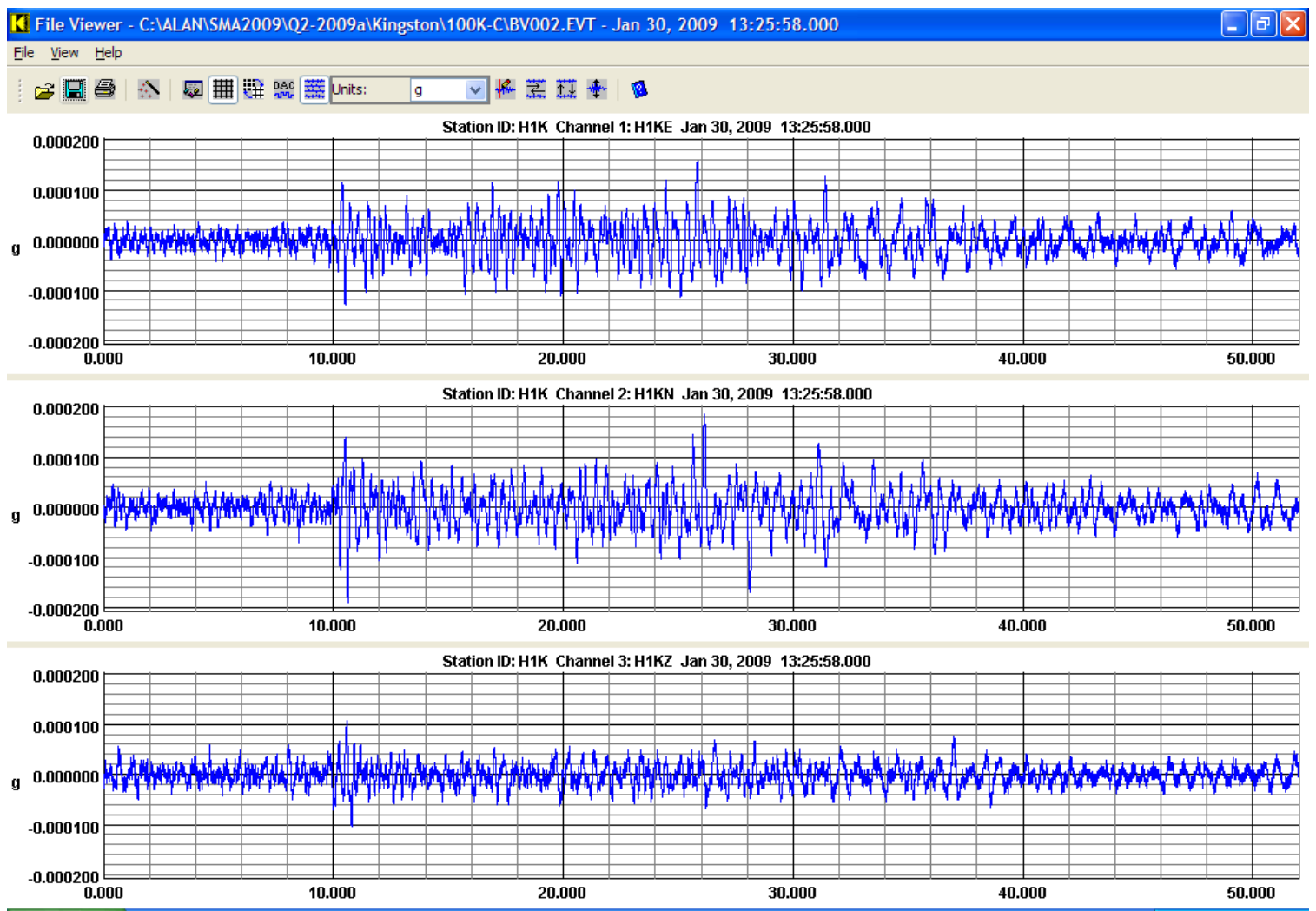

Figure 6.2. Acceleration Records from the January 30, 2009 Poulsbo Event at the $100 \mathrm{~K}$ Area SMA 



\subsection{Capabilities in the Event of a Significant Earthquake}

The SMA network was designed to provide ground motion data in areas at the Hanford Site that have high densities of people and/or facilities containing hazardous materials, to ensure that the Hanford Site is in compliance with DOE Order 420.1B, Chapter IV, Section 3.d, "Seismic Detection." The network also allows the HSAP to support Hanford Site emergency services organizations in complying with DOE Order G 420.1-1, Section 4.7, "Emergency Preparedness and Emergency Communications," by providing area ground motion data in the event of an earthquake on the Hanford Site. This section summarizes the capabilities of the HSAP in the event of an earthquake at Hanford.

Historically, only a few facilities at the Hanford Site had instruments to provide data on peak ground accelerations or any type of ground motion. The current SMA instruments were located so that if an earthquake occurred, ground motion data would be readily available to assess the damage at the 100-K Area, the 200 East and West Areas, and the 300 and 400 Area facilities, which have the greatest concentration of people and also contain hazardous materials (Moore and Reidel 1996).

Many facilities at the Hanford Site have undergone various degrees of seismic analysis, either during design or during requalification. Although the seismic design of a building may be known, when an earthquake is "felt" in a facility on the Hanford Site, a determination must be made as to the extent of damage before it can be reoccupied and the systems restarted. A "felt" earthquake may not cause any significant damage to a building but, without adequate characterization of the ground motion, initial determination of the building's possibility of having damage may be impossible.

In the event of a major regional earthquake such as the 2001 Nisqually event, building managers, emergency directors, and engineers can obtain ground motion data recorded by the SMA network from the HSAP in the Sigma V Building. This is done through the Hanford Site Emergency Services organization. Normal hours of operation for the HSAP are between 6 a.m. and 4:30 p.m., Monday through Friday. If a SMA is triggered, the HSAP will download events that were recorded and determine the peak ground accelerations. This information is then passed on to Hanford Site Emergency Services personnel where the facility engineers can use the data to determine if the ground motion exceeded, is equal to, or is less than the building design. This, along with assessments from trained engineers, allows the facility manager to make a rapid and cost-effective determination on whether a building is safe to re-occupy or should not be used until it has been inspected in more detail. Buildings that have designs exceeding the recorded ground motion could be put back into service very quickly; buildings with designs that are very close to or less than measured ground motion could be given priority for onsite damage inspections. 



\subsection{References}

Campbell NP. 1989. "Structural and Stratigraphic Interpretation of Rocks under the Yakima Fold Belt, Columbia Basin, Based on Recent Surface Mapping and Well Data." In Volcanism and Tectonism in the Columbia River Flood-Basalt Province, SP Reidel and PR Hooper (eds.), Special Paper 239, pp. 209-222. Geological Society of America, Boulder, Colorado.

Crosson RS. 1972. "Small Earthquakes, Structure and Tectonics of the Puget Sound Region." Bulletin of the Seismological Society of America 62(5):1133-1171.

DOE. 1988. Site Characterization Plan for the Reference Location, Hanford, WashingtonConsultation Draft. DOE/RW-0164, Vol. 1, U.S. Department of Energy, Washington, D.C.

DOE Order 420.1B, Chapter IV, Section 3.d. "Seismic Detection.” U.S. Department of Energy, Washington, D.C.

DOE Order G 420.1-1, Section 4.7. "Emergency Preparedness and Emergency Communications.” U.S. Department of Energy, Washington, D.C.

Fenneman NM. 1931. Physiography of Western United States. McGraw-Hill Book Company, Inc., New York.

Geomatrix. 1996. Probabilistic Seismic Hazard Analysis, DOE Hanford Site, Washington. WHC-SDW236A-TI-002, Rev. 1, Westinghouse Hanford Company, Richland, Washington.

Moore C and SP Reidel. 1996. Hanford Site Seismic Monitoring Instrumentation Plan. WHC-SD-GNER-30036, Westinghouse Hanford Company, Richland, Washington.

Reidel SP and KR Fecht. 1994a. Geologic Map of the Richland 1:100,000 Quadrangle, Washington. Open File Report 94-8, Division of Geology and Earth Resources, Washington State Department of Natural Resources, Olympia.

Reidel SP and KR Fecht. 1994b. Geologic Map of the Priest Rapids 1:100,000 Quadrangle, Washington. Open File Report 94-13, Division of Geology and Earth Resources, Washington State Department of Natural Resources, Olympia.

Reidel SP, NP Campbell, KR Fecht, and KA Lindsey. 1994. "Late Cenozoic Structure and Stratigraphy of South-Central Washington." In Regional Geology of Washington State, E Cheney and R Lasmanis (eds.), Bulletin 80, pp. 159-180. Division of Geology and Earth Resources, Washington State Department of Natural Resources, Olympia.

Reidel SP, KR Fecht, MC Hagood, and TL Tolan. 1989. "Geologic Development of the Central Columbia Plateau." In Volcanism and Tectonism in the Columbia River Flood-Basalt Province, SP Reidel and PR Hooper (eds.), Special Paper 239, pp. 247-264. Geological Society of America, Boulder, Colorado. 
Richter CF. 1958. Elementary Seismology. W. H. Freeman \& Company, San Francisco, California.

Rohay AC, DW Glover, and SD Malone. 1985. Time-Term Analysis of Upper Crustal Structure in the Columbia Basin, Washington. RHO-BW-SA-435 P, Rockwell Hanford Operations, Richland, Washington.

Rohay AC, MD Sweeney, DC Hartshorn, RE Clayton, and JL Devary. 2008a. Third Quarter Seismic Report for Fiscal Year 2008. PNNL-17830, Pacific Northwest National Laboratory, Richland, Washington. 


\section{Distribution}

Distribution of the Second Quarter Hanford Seismic Monitoring Report will be accomplished via download of electronic PDF files from an external PNNL website. The following organizations will be notified by letter with instructions to download the electronic document.

\section{OFFSITE}

Administrator

Kennewick General Hospital

P.O. Box 6128

Kennewick, WA 99336

R. Carson

Department of Geology

Whitman College

345 Boyer Avenue

Walla Walla, WA 99362

T. Conrads

Parsons Constructors, Inc.

3005 E. Ainsworth Street

Pasco, WA 99301

J. Schelling

Washington Emergency Management

Division

Building 20, M/S: TA-20

Camp Murray, WA 98430-5122

Idaho Geological Survey

Morrill Hall

University of Idaho

P.O. Box 443014

Moscow, ID 83844-3014

J. Kimball

Defense Nuclear Facilities Safety Board

625 Indiana Avenue NW, Suite 700

Washington, DC 20004
S. Lilligren

Nez Perce Tribe

P.O. Box 365

Lapwai, ID 83540

J. Litehiser

Bechtel National, Inc.

P.O. Box 193965

San Francisco, CA 94119-3965

Oregon Department of Geology and Mineral Industries

Suite 965, 800 NE Oregon Street \#28

Portland, OR 97232

ATTN: Library

I. Madin

N. Rasmussen

3140 Ravenshoe Drive

Las Vegas, NV 89134

S. P. Reidel

WSU Tri-Cities

2710 University Drive

Richland, WA 99354

P. Rizzo

105 Mall Boulevard

Suite 270E, Expo Mart

Monroeville, PA 15146

M. Stickney

Montana Bureau of Mines and Geology

Montana Tech University

Earthquake Studies Office

1300 West Park Street

Butte, MT 59701-8997 
University of Washington

Seismology Laboratory

Department of Earth and Space Sciences

Box 351310

Seattle, WA 98195-1310

ATTN: P. Bodin

R. Steele

J. Vidale

University of Washington

U.S. Geological Survey

Department of Earth and Space Sciences

Box 351310

Seattle, WA 98195-1310

ATTN: C. Weaver T. Yelin

U.S. Fish and Wildlife Service

3250 Port of Benton Boulevard

Richland, WA 99352

U.S. Geological Survey

Mail Stop 977

345 Middlefield Road

Menlo Park, CA 94025

ATTN: T. Brocher

Washington Division of Geology and Earth

Resources

P.O. Box 47007

Olympia, WA 98504-7007

ATTN: Library

T. Walsh

Washington State University

Department of Geology

P.O. Box 643420

Pullman, WA 99164-2812

R. Whale

Shell E\&P

200 N. Dairy Ashford

Houston, TX 77079

I. G. Wong

URS Corporation

1333 Broadway, Suite 800

Oakland, CA 94612
J. Zollweg

Boise State University

Department of Geosciences

Boise, ID 83725

\section{ONSITE}

DOE Richland Operations Office

B. L. Charboneau A6-33

K. L. Flynn $\quad$ A6-35

T. Y. Hale A7-89

R. D. Hildebrand A6-38

J. G. Morse A6-38

Y. T. Sherman A6-35

DOE Office of River Protection

R. A. Gilbert H6-60

M. R. Moreno H6-60

Washington River Protection Solutions

F. M. Mann

H6-03

\section{CH2M Hill Plateau Remediation Co.}

M. E. Brown

G5-51

J. T. Curtis

B3-15

S. A. Fargo

H8-60

S. M. Faulk

A3-05

B. H. Ford

E6-44

D. G. Horton

B6-06

M. I. Wood

H8-44 
Stoller

R. G. McCain

B2-62

Washington State Department of Ecology

J. Caggiano
$\mathrm{H} 0-57$
Pacific Northwest National Laboratory

R. E. Clayton

K6-75

J. L. Devary

K6-96

D. C. Hartshorn

K6-75

B. E. Opitz

K6-75

A. C. Rohay

K6-75

M. D. Sweeney

K6-75

Hanford Technical Library 


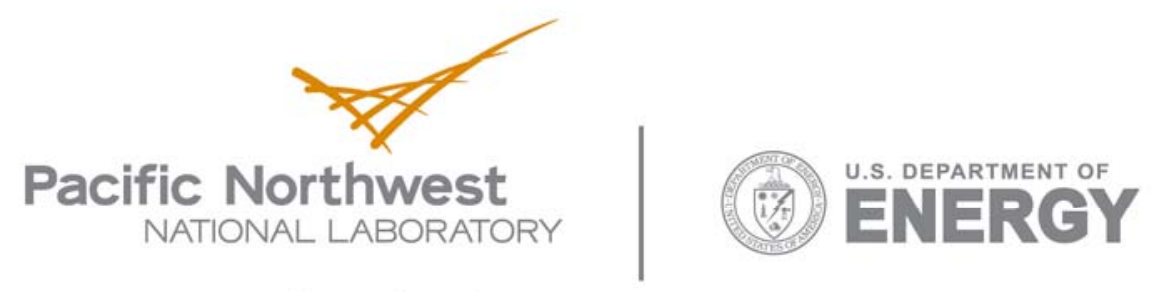

902 Battelle Boulevard

P.O. Box 999

Richland, WA 99352

1-888-375-PNNL (7665)

www.pnl.gov 